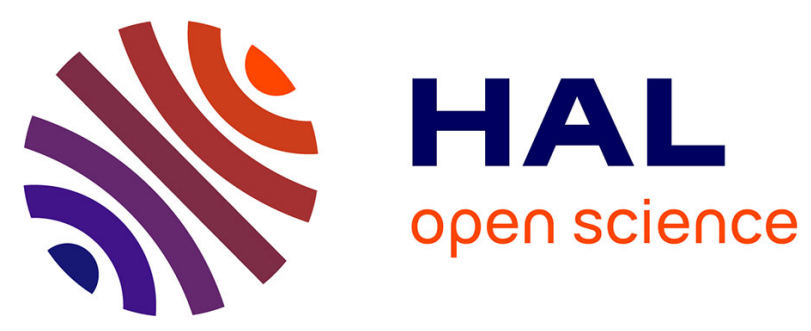

\title{
Circumferential Contouring of the Lower Trunk: Indications, Operative Techniques, and Outcomes-A Systematic Review
}

Raphael Carloni, Antoine de Runz, Benoit Chaput, Christian Herlin, Paul Girard, Eric Watier, Nicolas Bertheuil

\section{To cite this version:}

Raphael Carloni, Antoine de Runz, Benoit Chaput, Christian Herlin, Paul Girard, et al.. Circumferential Contouring of the Lower Trunk: Indications, Operative Techniques, and Outcomes-A Systematic Review. Aesthetic Plastic Surgery, 2016, 40 (5), pp.652-668. 10.1007/s00266-016-0660-7 . hal-01392032

\section{HAL Id: hal-01392032}

https://hal-univ-rennes1.archives-ouvertes.fr/hal-01392032

Submitted on 27 Feb 2017

HAL is a multi-disciplinary open access archive for the deposit and dissemination of scientific research documents, whether they are published or not. The documents may come from teaching and research institutions in France or abroad, or from public or private research centers.
L'archive ouverte pluridisciplinaire HAL, est destinée au dépôt et à la diffusion de documents scientifiques de niveau recherche, publiés ou non, émanant des établissements d'enseignement et de recherche français ou étrangers, des laboratoires publics ou privés. 


\section{Circumferential contouring of the lower trunk. Indications, Operative techniques and Outcomes. A Systematic Review.}

Raphael Carloni, Antoine De Runz, Benoit Chaput, Christian Herlin, Paul Girard, Eric Watier, Nicolas Bertheuil

\section{INTRODUCTION}

The increasing prevalence of obesity[1] and the development of bariatric surgery[2] have led to the gradual development of skin redraping techniques. Among them, circumferential body contouring allows the correction of redundant skin on the lower trunk after massive weight loss.

Several techniques have emerged since "circumferential dermolipectomy" was first described in 1940[3]. In the 1960s, Gonzalez-Ulloa[4] and Villain[5] described "belt lipectomy" and "circular lipectomy," implying circular resection performed up to the muscular aponeurosis at depth, with a posterior scar located at the belt line. In 1993, Lockwood[6] described the "lower body lift," which merged the medial thigh lift[7] with the transverse thigh-buttock lift[8] and incorporated two major innovations: a resection that preserved the superficial fascia and a lower-sited scar to help lift the lateral thigh and buttocks.

Carwell[9] and Van Geertruyden[10] described "circumferential torsoplasty," derived from belt lipectomy[4], and Lockwood improved his original technique[11].

The main innovations were high superior[12] and high lateral tension[13] abdominoplasty, buttock-autologous augmentation with[14] or without[1517] a flap, and lipogluteoplasty[17, 18]. 
Different techniques have been described under different names ("mid-body lift"[19], “circumferential body lift"[20], “central body lift"[21], "circumferential abdominoplasty"[22], "circular lipectomy"[23]); all derive from belt lipectomy or the lower body lift, depending on the level of posterior resection.

No systematic review of the literature on circumferential contouring of the lower trunk has been conducted to date. The aim of this review was to summarize the indications for, procedures and outcomes of, and patient satisfaction with these techniques.

\section{MATERIALS AND METHODS}

We undertook this review in June 2015 in accordance with the Preferred Reporting Items for Systematic Reviews and Meta-Analysis (PRISMA) statement $[24,25]$.

Our protocol was AMSTAR (Assessing the Methodological Quality of Systematic Reviews)-compliant and is available online at: www.crd.york.ac.uk/PROSPERO/display_record.asp?ID=CRD42015020680.

\section{Eligibility criteria}

The inclusion criteria were: published reports (original articles, randomized controlled trials, controlled clinical trials, retrospective or prospective observational studies, case reports, letters to the editor, and technical 
descriptions) that included patients undergoing circumferential contouring of the lower trunk, performed as single-step surgery.

The exclusion criteria were: two-step surgery, circumferential contouring of the upper trunk, isolated abdominoplasty or buttock lift, and circumferential liposuction without skin resection. We excluded all studies lacking original data and studies in any language other than English or French.

\section{Search strategy}

Eligible studies were identified from the PubMed and Cochrane Library databases using the following keywords combined with Boolean operators: «bodylift» $O R$ «body lift» OR «circumferential body contouring» OR «circumferential abdominoplasty» OR «lower body lift» OR «bodylifting» OR «circumferential contouring» $O R$ «belt lipectomy» OR «circumferential dermolipectomy» OR «truncal bodycontouring» OR «circumferential belt lipectomy»OR «circular lipectomy». Reference lists of selected articles were also examined to identify additional potentially eligible articles.

\section{Data collection}

Data were extracted independently by two researchers (RC, ADR), and disagreements were resolved by a third senior author (NB).

Data were collected on: authors, publication date, country, type of study and level of evidence, number of patients, indications, demographic data (body 
mass index [BMI], weight loss before surgery, medical history), perioperative care, operative technique, outcomes and complications.

\section{Statistical analysis}

Statistical analysis was performed using Prism 5 (GraphPad Software, La Jolla, CA, USA). A descriptive analysis of all data was carried out and results were expressed either in medians with inter-quartile-range (IQR) or in means with $95 \%$ confidence intervals.

\section{RESULTS}

Among the 3,424 articles initially identified by the search, 42 were finally selected (Fig. 1). Published between July 1960 and March 2015, they included 1,748 patients. Most had a low level of evidence (Table 1). The publications originated mainly from Western countries (Table 2, Fig. 2). Patients' characteristics, indications, and operative techniques are summarized in Tables 3 and 4.

\section{Indications}

The first described techniques[4, 5, 26-28] were indicated for obese women with redundant panniculus at the waistline following pregnancy or dieting. Lockwood's[6, 29] lower body lift no. 1 was indicated for normal-weight 
patients with soft-tissue laxity of the lower trunk and thighs. Carwell[9] was the first to include post-bariatric patients $(n=6)$.

The most frequently reported indication was massive weight $\operatorname{loss}[10,15,19$, $20,22,27,30-45]$ secondary to bariatric surgery or dieting, which created excess circumferential skin of the lower trunk. Posteriorly, belt lipectomy and derived techniques better treated hips and back rolls, whereas lower body lifts better treated buttocks and lateral thigh ptosis[33]. Belt lipectomy could also treat excess fat localized in the flanks in overweight or obese patients [4, $23,31,46]$.

Tobacco use was contraindicated in four studies [6, 15, 30, 37]. Contrarily, surgery on smokers was reported in 10 studies $[10,27,31,35,39,41-43,47$, 48]. Four studies each included surgery on patients with high blood pressure[21, 35, 39, 43] and diabetic patients[21, 35, 43, 47].

\section{Preoperative assessment}

Preoperative assessments were reported on in eight publications[19, 20, 32, 39, 40, 42, 44, 48]. Assessments included preoperative correction of anemia[14, 39, 40, 42, 44]; measurement of total protein[40, 44], prealbumin and albumin[44], glucose[44], iron[44], calcium[44], magnesium[44], thiamine[44], complete cell count[44], blood urea nitrogen[44], creatinine[44], electrolytes[19, 44, 48], and liver function[44]; and urinalysis[44]. Only two authors recommended follow up by a dietician[20] or nutritionist[42]. 


\section{Operative technique}

\section{Operative markings}

No difference in marking between men and women was reported. Markings were usually made while patients were standing[4, 33, 36-38, 43] and completed in the supine position [34, 35, 47]. "Pinch tests"[4, 21, 27, 42, 43, $46,47]$ were used to estimate the amount of tissue to be resected. Anteriorly, stretching forces proceeded from top to bottom, and posteriorly they were inverse[48]. Techniques derived from belt lipectomy resulted in scars situated at the waistline, whereas lower body lifts left scars situated at the bikini line (Fig. 3).

For belt lipectomy, the upper resection line was drawn first posteriorly, and ideally was placed at the superior margin of the flank rolls[19]. Then, a horizontal inferior line was drawn that crossed the interspinal line approximately $5 \mathrm{~cm}$ above the intergluteal groove[23].

For lower body lift, the lower resection line crossing the interspinal line inside or at the top of the gluteal cleft[48] was marked first. The upper resection line was usually $5 \mathrm{~cm}$ inferior to L5 [36].

For both techniques, the upper resection line was usually V-shaped[20, 26, $27,36]$ to preserve the gluteal aesthetic unit and decrease tension in the middle line. The upper line joined the central point to the posterior superior iliac spine[36, 43]. The height of tissue resected posteriorly ranged from 5 to $7 \mathrm{~cm}$ in the middle[23] and 10 to $15 \mathrm{~cm}$ laterally[21]. A grid pattern could be 
marked to facilitate closure[37]. The buttock flap was marked, if operated on, and ended laterally at the lateral limit of the inferior gluteal fold[14].

Laterally, the scar had to be located at the level of the anterior superior iliac spine[37]. On the mid-axillary line, the height of resection ranged from 10 to $25 \mathrm{~cm}[11],[23],[48]$. A triangular lateral excision to correct transversal lateral thigh excess was performed in some cases[49].

Anteriorly, the pattern joined the abdominoplasty scar, with a lower point of resection placed in the abdominal fold or $7 \mathrm{~cm}$ from the vulvar commissure or the base of the penis[48]. Associated medial thigh lift with a horizontal scar was reported by two authors[6, 39]. Gonzalez-Ulloa[4] associated "triangles of compensation" anteriorly and posteriorly to correct the transversal excess and to diminish the prominence of the mons Venus, when necessary. Liposuction areas were marked preoperatively.

\section{Patient positioning}

Three possibilities for positioning were reported:

- two-step positioning in the supine position first, then prone[4, 5, 19, 27, 33, $40,46]$

- two-step positioning in the prone position first, then supine (the most commonly reported technique) $[9,10,14,15,20-22,36-39,42,43,48]$; and - three-step positioning, with the patient supine and in two lateral decubitus positions $[6,23,26,34,35,47,49,50]$. This installation was chosen for better control of the lateral thigh lift and when lateral thigh resection was required[49], and was used in the USA[6, 23, 26, 34, 35, 49, 50] and UK[47]. 
We describe the different surgical techniques using the most common positioning sequence.

\section{Posterior Resection}

The depth of resection varied among studies (Fig. 4). Belt lipectomy-derived techniques used resection deep to the muscular fascia[4, 5] or to the superficial fascia[19, 21]. The resection depth for the lower body lift was also to the muscular fascia[26, $35,37,38,40,43]$ or the superficial fascia[6, 11, 15, 39, 47]. Lockwood[6] was the first to report the associated use of liposuction.

In 2002, the first buttock auto-augmentation with a flap[14] was reported (Fig. 5). The flap measured approximately $10 \times 25 \mathrm{~cm}$ and extended laterally to the end of the buttock fold. Other derived flaps were described: a lateral perforator-based deepithelized dermal fat flap[34], a random medially based flap[33], the "moustache flap"[20], and a superior gluteal artery perforator flap[36]. Augmentation flaps were reported in 9 of 42 publications.

The technique of buttock augmentation without flap included sutures in an outer-inner direction[15, 17, 33] (Fig. 6) or a "purse string" suture[16].

Finally, the most conservative technique for posterior resection was lipogluteoplasty, which involved skin-only resection after liposuction under the zone to be resected[18].

\section{Anterior resection}


This approach consisted of abdominoplasty associated with rectus fascia plicature, where a diastasis existed, and transposition of the umbilicus. It was combined in some cases with liposuction[21,37, 38, 48] and a high superior tension[42] or high lateral tension technique[14, 40]. Associated performance of monsplasty to treat mons Venus ptosis was also reported[40].

\section{Thigh lift}

Lockwood's[6] lower body lift no. 1 provided a medial thigh lift with a horizontal scar in the inguinal fold and an anchor to the Colles fascia. Kitzinger[39] also reported the associated performance of a medial thigh lift. The lateral thigh lift, as described in Lockwood's[11] lower body lift no. 2, was used much more frequently[10, 23, 26, 31, 34, 35]. It consisted of liposuction and minimal undermining of the trochanteric region to lift the lateral thigh. Suspension points were eventually added[14, 48]. Davison[49] performed triangular resection of the lateral thigh to correct excess skin in this area.

\section{Outcomes and complications}

All main data were summarized in Table 5. The median percentage of patients who had a complication was $36,55[26,63-45,65] \%$. The median revision rate for a non-aesthetic purpose (wound dehiscence, abscess, skin necrosis, fat necrosis, seroma evacuation, hematoma) was 3,5 [0,25-6]\%. The median revision rate for aesthetic purpose (scar revision, secondary 
liposuction or fat injection and correction of omblic) was $0[0-5,75] \%$. In the posterior step, 6 cases of gluteal fat necrosis were reported in 4 series $[20,33$, $34,36]$ and 48 cases of gluteal hypoesthesia were reported in two studies[32, 48].

\section{Antibiotic prophylaxis}

Antibiotic prophylaxis was not well codified (Table 6). Some authors recommended intraoperative prophylaxis[10, 22, 23, 42]; others recommended antibiotherapy for 24 hours[38], 48 hours[14, 32], 3 days[39], or 5 days[47] postoperatively. Many teams treated their patients until removal of drains $[11,19,20,26,29,35,36,46]$. All antibiotics used were first- or second-generation cephalosporins. First-generation cephalosporins included cephalexin[6, 29], cephalothin[22, 23], and cefazolin[19, 42], all administered at a dose of $1-2 \mathrm{~g}$ perioperatively, then $1 \mathrm{~g}$ three times per day if continued[38]. The second-generation cephalosporin was cefuroxime, which was prescribed at a dose of 1.5-2 g[39]' [47] perioperatively, then $2 \mathrm{~g}$ twice a day[39] if continued.

\section{Thromboprophylaxis}

Most authors recommended early ambulation $[5,10,19,20,23,30-32,35-37$, $42,44,47,48]$ and the use of compression stockings $[10,14,22,26,30,37$, 39, 42, 47]. Prophylactic anticoagulation $[10,19,21-23,32,38-40,42,48]$ and the use of pneumatic compression stockings $[9,19-21,31,35,36,40,47]$ 
were noted in several publications (Table 7). When thromboprophylaxis was described, it was performed with low-molecular-weight enoxaparin (3000 UI twice a day[21], 4000 UI per day[38, 42, 51], or 5000 UI[23] per day) or unfractionated heparin (5000 UI per day[40]). The use of fondaparinux was mentioned in only one publication[20].

Anticoagulants were first administered 1 hour before surgery[21] or 4 hours after surgery[19]. The duration of thromboprophylaxis varied among studies: for 2 days after surgery[40], until hospital discharge[19]'[21], and for 1 week[48], 2 weeks[42], and 6 weeks[39] after discharge. Nemerofsky[35] performed Doppler ultrasound before discharge to eliminate thromboembolism.

\section{Patient satisfaction and quality of life}

Only one prospective study[52] assessed quality of life (QOL) and patient satisfaction in 27 patients after circumferential body lift of the lower trunk using a validated questionnaire (WHOQOL-BREF survey for QOL and FbeK for patient satisfaction). Operated patients showed a highly significant increase in global QOL, physical and psychological health, social relationships, and environment (WHOQOL-BREF; all $p<0.01$ ). The FbeK results showed significant lower scores on the "insecurity and uneasiness" scale after bodylifting $(p<0.01)$ and a greater attractiveness and selfconfidence scores after surgery $(p<0.001)$.

Five studies assessed patient satisfaction using non-validated questionnaires[27, 36, 41-43]. Patient satisfaction with aesthetic outcomes 
after belt lipectomy was evaluated by a 1-10 visual analog scale and showed improved results[27]. Baca[41] showed an average overall improvement to scores of 9.4/10. A similar result was observed after lower body lift with autologous augmentation, with assessment using a 1-5 scale (4.35 \pm 0.63)[36]. De Runz[42] evaluated overall satisfaction (55.8\% excellent results), abdomen satisfaction (55.8\% excellent results), buttocks satisfaction (32.7\% excellent results), and QOL (improved in $73.1 \%$ of patients). No difference in satisfaction was found between buttock auto-augmentation and non-augmentation[43]. The authors of 10 studies[9, 10, 14, 21, 22, 30, 34, 35, 40, 48] reported high or very high satisfaction from all patients, without explanation of the evaluation method.

\section{DISCUSSION}

Circumferential contouring of the lower trunk procedures were initially created to treat circumferential excess skin of the lower trunk in nonbariatric patients[4-6], and progressed to the treatment of patients who had undergone massive weight loss[9]. Massive weight loss, defined in the literature as a loss of $50 \%$ of excess weight[53], is the most appropriate indication.

In this case, excess (redundant) circumferential skin is present and cannot be corrected by abdominoplasty or simple liposuction[30]. Excess posterior skin requires belt lipectomy or lower body lift, depending on the deformation. 
This review provides the first overview of circumferential body contouring of the lower trunk, and the various techniques, indications, and complications, with analysis of findings in 1,748 operated patients. The majority of published series were American and European, in connection with the prevalence of obesity on these continents.

\section{Patients eligible for operation}

Patients should have stable weight for at least 6[30] or 12[39, 44] months before surgery, ideally with BMI $<35 \mathrm{~kg} / \mathrm{m}^{2}[35,39]$. More women than men underwent surgery, probably for three main reasons: the global prevalences of obesity and overweight are higher in women than in men (13.7\% vs. $9.3 \%$ and $37.3 \%$ vs. $35.9 \%$, respectively)[1]; more bariatric surgeries are performed on women[2]; and women are more concerned about their appearance[54].

\section{Optimal preoperative assessment}

Anemia screening and nutritional assessment are very important. Surgery is often hemorrhagic, and anemia should be detected and corrected preoperatively[14, 42] to avoid high transfusion rates[6]. Colwell[36] recommended a baseline hemoglobin concentration of $12 \mathrm{~g} / \mathrm{dl}$.

Post-bariatric patients often present nutritional deficiencies (iron, ferritin, hemoglobin, thiamine, 25-OH vitamin D, vitamin A, vitamin B12, zinc, selenium, and folate)[55], aggravated by low compliance (60\%) with vitamin 
and mineral supplementation. Such deficiencies are maximal in the first year following bariatric surgery[56] and should be corrected preoperatively to reduce surgical complications, especially wound problems[57]. Fischer[58] demonstrated that preoperative albumin levels and malnutrition were associated with increased odds of minor wound complications in all body contouring procedures. Nutritional deficiencies create biomechanical changes in the $\operatorname{skin}[59,60]$ that delay wound healing.

Austin[61] demonstrated the positive impact of protein nutritional supplementation on abdominoplasty, with a decrease in wound dehiscence. We believe that the same preoperative assessment should be performed for circumferential body contouring. Nutrition should be controlled not only preoperatively, but also after surgery with protein supplementation[62].

\section{Current trends in technique}

Belt lipectomy was the first technique described in the literature[4], whereas lower body lift[6, 11, 29] is most popular. A gluteal augmentation flap[14], supplied by perforators from the superior gluteal artery, lateral sacral arteries, and lumbar artery[14, 20,33], can be added to correct insufficient buttock projection. Colwell[36] showed that major perforators are generally situated 6-9 $\mathrm{cm}$ from the midline, whereas Nojima[63] placed them $10-12 \mathrm{~cm}$ from the midline.

Despite the effect on gluteal projection, these techniques may actually increase the complication rate[43]. We noted that gluteal fat necrosis[20, 33, 
34, 36] and gluteal hypoesthesia[14, 48] were reported only in patients who were treated with auto-augmentation flaps.

The most conservative and safe procedure is probably "lipogluteoplasty" [17, 18], which uses a technique similar to that used in brachioplasties [64] and medial thigh lifts $[65,66]$, with skin resection just under the dermis with no undermining. It can eventually be combined with buttock augmentation techniques without flap[15-17]. Resection under the dermis after liposuction is even more conservative in terms of the blood and lymphatic systems[18, 67]. When deeper resection is performed, the use of fibrin sealant during surgery[33] and quilting sutures[20] may reduce dead spaces.

We identified no study of fat grafting into buttocks. This situation is probably due to the risk of reduced graft survival, as the patient lies on the grafted fat during the postoperative course[20].

\section{Complications}

Since the $50 \%$ complication rate described by Lockwood[6], the complications rate has decreased among published reports, with a mean of $37 \%$. This rate is comparable to that for abdominoplasties (between 18\%[68] to $40 \%[69]$ ) and brachioplasties (from $20 \%[70,71]$ to $56 \%[64]$ ). It remains lower than medial thigh lifts $(43-74 \%[72,73])$. Major complications are uncommon and the most frequent complications are minor: seroma, wound dehiscence, and scar irregularities. Wound dehiscences may be prevented by stop smoking and supplementing nutritional carencies before surgery[57]; seromas by the use of fibrin sealant during surgery[33]; quilting sutures to 
reduce dead space[20]; wearing a compression garment for 6 weeks[42]. The usually reported idea is that preserving superficial fascia is essential to diminish seromas. Making a resection under the dermis after a liposuction seems even more conservative towards the blood and lymphatic system[18, 67] . Gluteal hypoesthesia and gluteal fat necrosis only occurred in patients who had a gluteal augmentation with flap.

Post bariatric patients were associated with a higher complications rate during abdominoplasties, especially healing problems[74],[75]. This was not reported during circumferential procedures[38, 42]. However this surgery was intented for massive weight loss patients, creating a selection bias.

Our review confirmed that, when combining different body contouring techniques such as lower body lift and medial thighplasty[6, 39], complication rate increases $[76,77]$.

Although minor complications are frequent, circumferential contouring of the lower trunk should be proposed whenever it is indicated, because the quality of life is improved[52]. In this surgery, the benefit to patients is mainly functional, not esthetic.

\section{Antibiotic prophylaxis}

The infection rate after circumferential contouring of the lower trunk was similar to that following abdominoplasty (7\%[68]-8\%[78]). For abdominoplasty, antibiotic prophylaxis was recommended[79, 80]. For circumferential contouring, further specific studies are necessary to assess the efficacy of antibiotic prophylaxis. 


\section{Thromboprophylaxis}

Patients undergoing circumferential procedures of the lower trunk should always be considered to be at high risk of thromboembolism[81, 82]. Hatef[51] found that enoxaparin administration was associated with a decrease in deep venous thrombosis in patients undergoing circumferential abdominoplasty. For all body contouring procedures, he reported BMI > 30 $\mathrm{kg} / \mathrm{m}^{2}$, hormone therapy, and circumferential abdominoplasty as risk factors for thromboembolism and recommended systematic thromboprophylaxis in these cases[51]. Similar results[83] were reported among patients undergoing procedures after bariatric surgery with BMIs $>35 \mathrm{~kg} / \mathrm{m}^{2}$.

Based on this review, we strongly recommend chemoprophylaxis associated with early ambulation and the use of compression stockings (standard patients) or pneumatic stockings (high-risk patients). The risk of phlebitis is slightly higher[51] than for abdominoplasty, but it can be reduced by these simple measures.

The timing of administration of the first dose varied among studies, with no difference in intraoperative blood loss, postoperative bleeding, or thromboembolism[51]. Independently of the timing, chemical thromboprophylaxis was associated with increased rates of hematoma[39] and postoperative bleeding[51]. This situation explains why some authors did not administer heparin[35]. In our opinion, phlebitis poses a greater risk than does hematoma. 


\section{Methodological issues}

Our review was limited in that the majority of studies included were lowevidence studies, e.g., retrospective series. Only two studies were prospective[39, 52]. Data concerning patient characteristics, operative techniques, and outcomes were reasonably well reported, even if means were often preferred to raw data; data concerning weight loss before surgery, preoperative assessment, use of liposuction, antibiotic prophylaxis, and thromboprophylaxis were poor. Populations were fairly heterogeneous, with differences in patient characteristics and operative techniques among studies. Further prospective studies should be designed using detailed data reporting and more strict inclusion criteria.

Only two studies were excluded because of language[84, 85], which reduced the language bias and rendered our review reasonably comprehensive. Other biases included publication bias and detection bias, as most study data were analyzed retrospectively.

\section{CONCLUSION}

To date, no clear guidelines exist for circumferential lower trunk contouring indications and contraindications. The popularity of these procedures will increase over the next few years, in parallel with the worldwide prevalence of obesity. Greater accuracy is required concerning preoperative assessment of patients, selected BMI ranges, and preoperative risk evaluation. To achieve this accuracy, better-quality studies are required to improve the ability to 
analyze patient characteristics and outcomes. Future work will evolve in two directions: more highly defined indications established by physicians and improved information regarding surgical risks for patients.

\section{REFERENCES}

1. WHO Obesity and overweight. In: WHO. http://www.who.int/mediacentre/factsheets/fs311/en/.

2. Fuchs HF, Broderick RC, Harnsberger CR, et al. (2015) Benefits of bariatric surgery do not reach obese men. J Laparoendosc Adv Surg Tech A 25:196-201.

3. Somalo M (1940) Dermolipectomia circular del tronco. Semana Med $47: 1435-43$.

4. Gonzalez-Ulloa M (1960) Belt lipectomy. Br J Plast Surg 13:179-186.

5. Vilain R, Dubousset J (1964) [TECHNICS AND INDICATIONS ON CIRCULAR LIPECTOMY. APROPOS OF 150 OPERATIONS]. Ann Chir 18:289-300.

6. Lockwood T (1993) Lower body lift with superficial fascial system suspension. Plast Reconstr Surg 92:1112-1122.

7. Lockwood TE (1988) Fascial anchoring technique in medial thigh lifts. Plast Reconstr Surg 82:299-304.

8. Lockwood TE (1991) Transverse flank-thigh-buttock lift with superficial fascial suspension. Plast Reconstr Surg 87:1019-1027.

9. Carwell GR, Horton CE (1997) Circumferential torsoplasty. Ann Plast Surg 38:213-216.

10. Van Geertruyden JP, Vandeweyer E, de Fontaine S, et al. (1999) Circumferential torsoplasty. Br J Plast Surg 52:623-628.

11. Lockwood TE (2001) Lower-body lift. Aesthetic Surg J Am Soc Aesthetic Plast Surg 21:355-370.

12. Le Louarn C, Pascal JF (2000) High superior tension abdominoplasty. Aesthetic Plast Surg 24:375-381. 
13. Lockwood T (1995) High-lateral-tension abdominoplasty with superficial fascial system suspension. Plast Reconstr Surg 96:603-615.

14. Pascal JF, Le Louarn C (2002) Remodeling bodylift with high lateral tension. Aesthetic Plast Surg 26:223-230.

15. Koller M, Hintringer T (2012) Circumferential superficial fascia lift of the lower trunk: surgical technique and retrospective review of 50 cases. J Plast Reconstr Aesthetic Surg JPRAS 65:433-437.

16. Koller $M$, Hintringer $T$ (2012) A less invasive technique for gluteal autoaugmentation during bodylifting of the lower trunk: the purse string suture in the non elevated area. J Plast Reconstr Aesthetic Surg JPRAS $65: 535-536$.

17. Bertheuil N, Carloni R, Herlin C, et al. (2016) Lower Body Lift after massive weight loss: Autoaugmentation versus no Augmentation. Plast Reconstr Surg 137:476e-7e.

18. Koller M (2015) The lipogluteoplasty in circumferential bodylifting. Plast Reconstr Surg Glob Open 3:e303.

19. Strauch B, Herman C, Rohde C, Baum T (2006) Mid-body contouring in the post-bariatric surgery patient. Plast Reconstr Surg 117:2200-2211.

20. Centeno RF (2006) Autologous gluteal augmentation with circumferential body lift in the massive weight loss and aesthetic patient. Clin Plast Surg 33:479-496.

21. Rohrich RJ, Gosman AA, Conrad MH, Coleman J (2006) Simplifying circumferential body contouring: the central body lift evolution. Plast Reconstr Surg 118:525-535.

22. Modolin M, Cintra W, Gobbi CIC, Ferreira MC (2003) Circumferential abdominoplasty for sequential treatment after morbid obesity. Obes Surg 13:95-100.

23. Morales Gracia HJ (2003) Circular lipectomy with lateral thigh-buttock lift. Aesthetic Plast Surg 27:50-57.

24. Moher D, Liberati A, Tetzlaff J, et al. (2010) Preferred reporting items for systematic reviews and meta-analyses: the PRISMA statement. Int J Surg Lond Eng1 8:336-341.

25. Liberati A, Altman DG, Tetzlaff J, et al. (2009) The PRISMA statement for reporting systematic reviews and meta-analyses of studies that evaluate healthcare interventions: explanation and elaboration. BMJ 339:b2700.

26. Hamra S (1999) Circumferential body lift. Aesthet Surg J 19:244-250. 
27. van Huizum MA, Roche NA, Hofer SOP (2005) Circular belt lipectomy: a retrospective follow-up study on perioperative complications and cosmetic outcome. Ann Plast Surg 54:459-464.

28. Cormenzana P, Samprón NM (2004) Circumferential approach to contouring of the trunk. Aesthetic Surg J Am Soc Aesthetic Plast Surg $24: 13-23$.

29. Lockwood $T$ (1996) The role of excisional lifting in body contour surgery. Clin Plast Surg 23:695-712.

30. Heddens CJ (2001) Belt lipectomy: procedure and outcomes. Plast Surg Nurs Off J Am Soc Plast Reconstr Surg Nurses 21:185-189, 199; quiz 191.

31. Aly AS, Cram AE, Chao M, et al. (2003) Belt lipectomy for circumferential truncal excess: the University of Iowa experience. Plast Reconstr Surg 111:398-413.

32. Pascal JF, Le Louarn C (2004) [Bodylift complications]. Ann Chir Plast Esthét 49:605-609.

33. Rohde C, Gerut ZE (2005) Augmentation buttock-pexy using autologous tissue following massive weight loss. Aesthetic Surg J Am Soc Aesthetic Plast Surg 25:576-581.

34. Sozer SO, Agullo FJ, Wolf C (2005) Autoprosthesis buttock augmentation during lower body lift. Aesthetic Plast Surg 29:133-137; discussion $138-140$.

35. Nemerofsky RB, Oliak DA, Capella JF (2006) Body lift: an account of 200 consecutive cases in the massive weight loss patient. Plast Reconstr Surg 117:414-430.

36. Colwell AS, Borud LJ (2007) Autologous gluteal augmentation after massive weight loss: aesthetic analysis and role of the superior gluteal artery perforator flap. Plast Reconstr Surg 119:345-356.

37. Kolker AR, Lampert JA (2009) Maximizing aesthetics and safety in circumferential-incision lower body lift with selective undermining and liposuction. Ann Plast Surg 62:544-548.

38. Vico PG, De Vooght A, Nokerman B (2010) Circumferential body contouring in bariatric and non-bariatric patient. J Plast Reconstr Aesthetic Surg JPRAS 63:814-819.

39. Kitzinger HB, Cakl T, Wenger R, et al. (2013) Prospective study on complications following a lower body lift after massive weight loss. J Plast Reconstr Aesthetic Surg JPRAS 66:231-238.

40. Buchanan PJ, Nasajpour H, Mast BA (2013) Safety and efficacy of outpatient lower body lifting. Ann Plast Surg 70:493-496. 
41. Baca ME, Neaman KC, Renucci JD (2014) Outpatient circumferential abdominoplasty in the non post-bariatric surgery patient. Plast Reconstr Surg 134:128-9.

42. de Runz A, Brix $M$, Gisquet $H$, et al. (2015) Satisfaction and complications after lower body lift with autologous gluteal augmentation by island fat flap: 55 case series over 3 years. J Plast Reconstr Aesthetic Surg JPRAS 68:410-418.

43. Srivastava U, Rubin JP, Gusenoff JA (2015) Lower body lift after massive weight loss: autoaugmentation versus no augmentation. Plast Reconstr Surg 135:762-772.

44. Aly A, Mueller M (2014) Circumferential truncal contouring: the belt lipectomy. Clin Plast Surg 41:765-774.

45. Shermak MA, Rotellini-Coltvet LA, Chang D (2008) Seroma development following body contouring surgery for massive weight loss: patient risk factors and treatment strategies. Plast Reconstr Surg 122:280-288.

46. Hunstad JP (1996) Body contouring in the obese patient. Clin Plast Surg 23:647-670.

47. Jones BM, Toft NJ (2008) Bodylifting: indications, technique and complications. J Plast Reconstr Aesthetic Surg JPRAS 61:730-735.

48. Dini M, Mori A, Cassi LC, et al. (2008) Circumferential abdominoplasty. Obes Surg 18:1392-1399.

49. Davison SP, Clemens MW, Chang S (2007) Modified circumferential torsoplasty for the massive-weight-loss patient. Ann Plast Surg 59:453458.

50. Aly A, Cram A (2008) The Iowa belt lipectomy technique. Plast Reconstr Surg 122:959-960.

51. Hatef DA, Kenkel JM, Nguyen MQ, et al. (2008) Thromboembolic risk assessment and the efficacy of enoxaparin prophylaxis in excisional body contouring surgery. Plast Reconstr Surg 122:269-279.

52. Koller M, Schubhart S, Hintringer T (2013) Quality of life and body image after circumferential body lifting of the lower trunk: a prospective clinical trial. Obes Surg 23:561-566.

53. Shermak MA, Chang D, Magnuson TH, Schweitzer MA (2006) An outcomes analysis of patients undergoing body contouring surgery after massive weight loss. Plast Reconstr Surg 118:1026-1031.

54. Giordano S, Victorzon M, Stormi T, Suominen E (2014) Desire for body contouring surgery after bariatric surgery: do body mass index and 
weight loss matter? Aesthetic Surg J Am Soc Aesthetic Plast Surg 34:96105.

55. Agha-Mohammadi S, Hurwitz DJ (2008) Nutritional deficiency of postbariatric surgery body contouring patients: what every plastic surgeon should know. Plast Reconstr Surg 122:604-613.

56. Agha-Mohammadi S, Hurwitz DJ (2008) Potential impacts of nutritional deficiency of postbariatric patients on body contouring surgery. Plast Reconstr Surg 122:1901-1914.

57. Agha-Mohammadi S, Hurwitz DJ (2010) Enhanced recovery after bodycontouring surgery: reducing surgical complication rates by optimizing nutrition. Aesthetic Plast Surg 34:617-625.

58. Fischer JP, Wes AM, Serletti JM, Kovach SJ (2013) Complications in body contouring procedures: an analysis of 1797 patients from the 2005 to 2010 American College of Surgeons National Surgical Quality Improvement Program databases. Plast Reconstr Surg 132:1411-1420.

59. Fearmonti RM, Blanton M, Bond JE, et al. (2012) Changes in dermal histomorphology following surgical weight loss versus diet-induced weight loss in the morbidly obese patient. Ann Plast Surg 68:507-512.

60. Light D, Arvanitis GM, Abramson D, Glasberg SB (2010) Effect of weight loss after bariatric surgery on skin and the extracellular matrix. Plast Reconstr Surg 125:343-351.

61. Austin RE, Lista F, Khan A, Ahmad J (2015) The Impact of Protein Nutritional Supplementation for Massive Weight Loss Patients Undergoing Abdominoplasty. Aesthetic Surg J Am Soc Aesthetic Plast Surg.

62. Michaels J, Coon D, Rubin JP (2011) Complications in postbariatric body contouring: postoperative management and treatment. Plast Reconstr Surg 127:1693-1700.

63. Nojima K, Brown SA, Acikel C, et al. (2006) Defining vascular supply and territory of thinned perforator flaps: Part II. Superior gluteal artery perforator flap. Plast Reconstr Surg 118:1338-1348.

64. de Runz A, Colson T, Minetti C, et al. (2015) Liposuction-assisted medial brachioplasty after massive weight loss: an efficient procedure with a high functional benefit. Plast Reconstr Surg 135:74e-84e.

65. Bertheuil N, Carloni R, De Runz A, et al. (2016) Medial thighplasty: Current concepts and practices. Ann Chir Plast Esthet 61:1e-7e.

66. Le Louarn C, Pascal JF (2004) The concentric medial thigh lift. Aesthetic Plast Surg 28:20-23. 
67. Bertheuil N, Chaput B, Berger-Müller S, et al. (2015) Liposuction Preserves the Morphological Integrity of the Microvascular Network: Flow Cytometry and Confocal Microscopy Evidence in a Controlled Study. Aesthetic Surg J Am Soc Aesthetic Plast Surg.

68. Stewart KJ, Stewart DA, Coghlan B, et al. (2006) Complications of 278 consecutive abdominoplasties. J Plast Reconstr Aesthetic Surg JPRAS 59:1152-1155.

69. Momeni A, Heier M, Bannasch H, Stark GB (2009) Complications in abdominoplasty: a risk factor analysis. J Plast Reconstr Aesthetic Surg JPRAS 62:1250-1254.

70. Knoetgen J, Moran SL (2006) Long-term outcomes and complications associated with brachioplasty: a retrospective review and cadaveric study. Plast Reconstr Surg 117:2219-2223.

71. Symbas JD, Losken A (2010) An outcome analysis of brachioplasty techniques following massive weight loss. Ann Plast Surg 64:588-591.

72. Gusenoff JA, Coon D, Nayar H, et al. (2015) Medial thigh lift in the massive weight loss population: outcomes and complications. Plast Reconstr Surg 135:98-106.

73. Bertheuil N, Thienot S, Huguier V, et al. (2014) Medial thighplasty after massive weight loss: are there any risk factors for postoperative complications? Aesthetic Plast Surg 38:63-68.

74. Lievain L, Aktouf A, Auquit-Auckbur I, et al. (2015) [Abdominoplasty complications: particularities of the post-bariatric patients within a 238 patients series]. Ann Chir Plast Esthét 60:26-34.

75. Staalesen T, Olsén MF, Elander A (2012) Complications of abdominoplasty after weight loss as a result of bariatric surgery or dieting/postpregnancy. J Plast Surg Hand Surg 46:416-420.

76. Chaput B, Bertheuil N, Alet Jm, et al. (2016) Combined Abdominoplasty and Breast Surgery vs. Isolated Abdominoplasty: Results of a Metaanalysis. Plast Reconstr Surg 137:248e-9e.

77. Michot A, Alet J-M, Pélissier P, et al. (2016) Morbidity in combinedprocedure associating abdominoplasty and breast surgery: A systematic review. Ann Chir Plast Esthet 61:9e-19e.

78. Grieco M, Grignaffini E, Simonacci F, Raposio E (2015) Analysis of Complications in Postbariatric Abdominoplasty: Our Experience. Plast Surg Int 2015:209173.

79. Sevin A, Senen D, Sevin K, et al. (2007) Antibiotic use in abdominoplasty: prospective analysis of 207 cases. J Plast Reconstr Aesthetic Surg JPRAS 60:379-382. 
80. Hurvitz KA, Olaya WA, Nguyen A, Wells JH (2014) Evidence-based medicine: Abdominoplasty. Plast Reconstr Surg 133:1214-1221.

81. Hatef DA, Trussler AP, Kenkel JM (2010) Procedural risk for venous thromboembolism in abdominal contouring surgery: a systematic review of the literature. Plast Reconstr Surg 125:352-362.

82. Iorio ML, Venturi ML, Davison SP (2015) Practical guidelines for venous thromboembolism chemoprophylaxis in elective plastic surgery. Plast Reconstr Surg 135:413-423.

83. Shermak MA, Chang DC, Heller J (2007) Factors impacting thromboembolism after bariatric body contouring surgery. Plast Reconstr Surg 119:1590-1596; discussion 1597-1598.

84. Reichenberger MA, Stoff A, Richter DF (2007) [Body contouring surgery in the massive weight loss patient]. Chir Z Für Alle Geb Oper Medizen $78: 326-334$.

85. Gonzalez-Ulloa M (1959) [Circular lipectomy with transposition of the umbilicus and aponeurolytic plastic technic]. Cir Cir 27:394-409. 


\section{FIGURE LEGENDS}

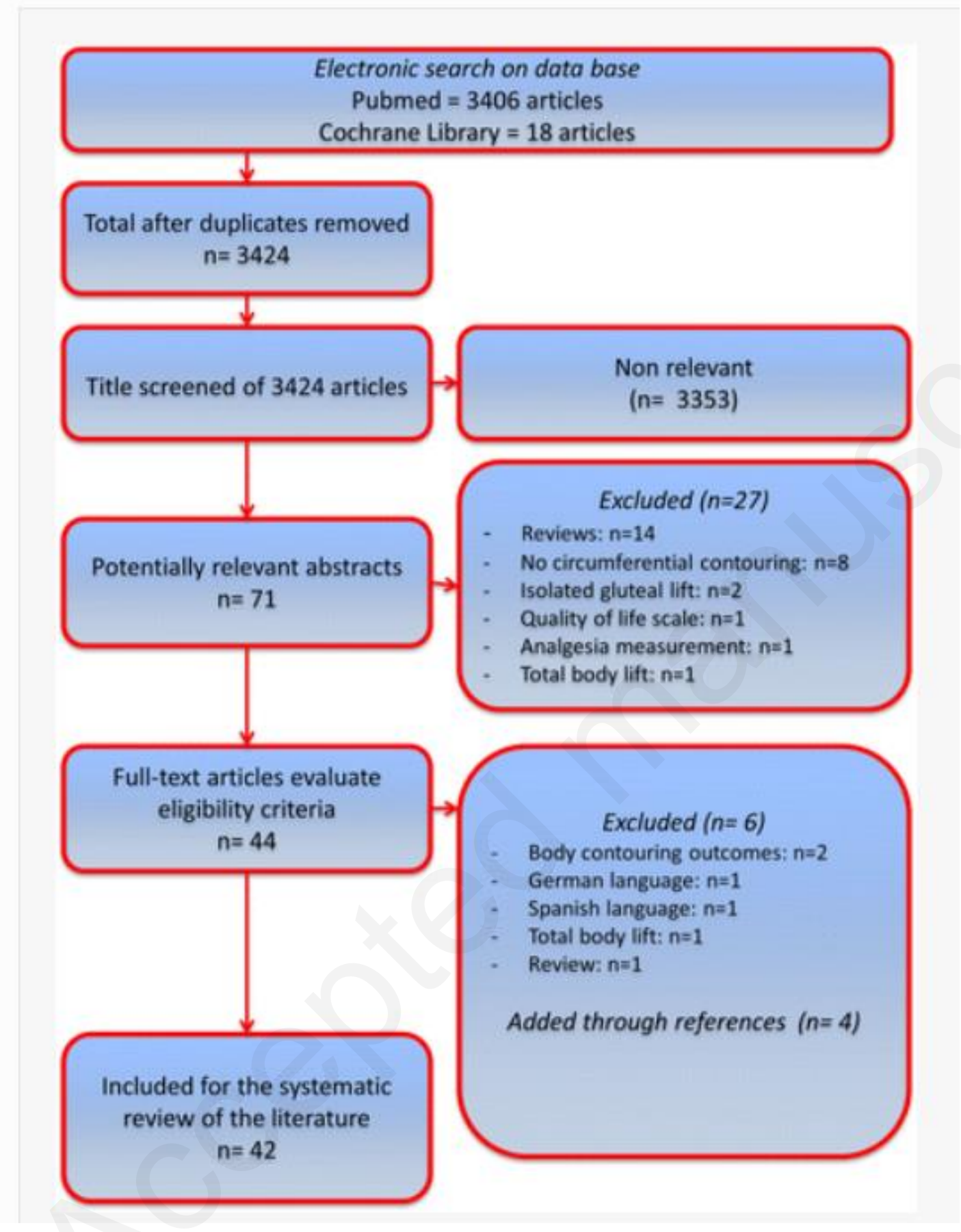

Figure 1. Prisma flow chart of the systematic review. 


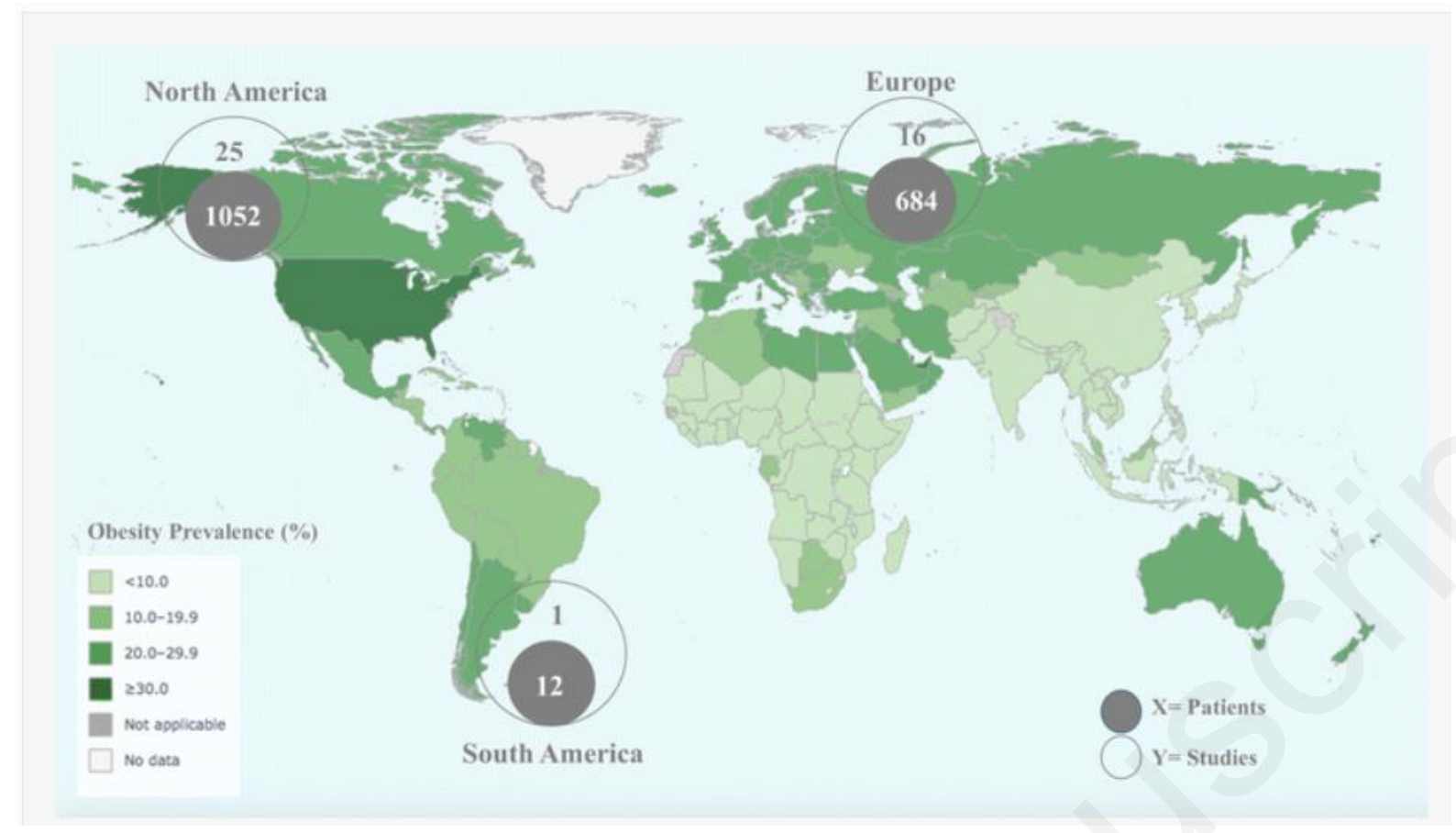

Figure 2. Obesity prevalence

(gamapserver.who.int/gho/interactive_charts/ncd/risk_factors/obesity/atlas.html) and geographical distribution of publications. 


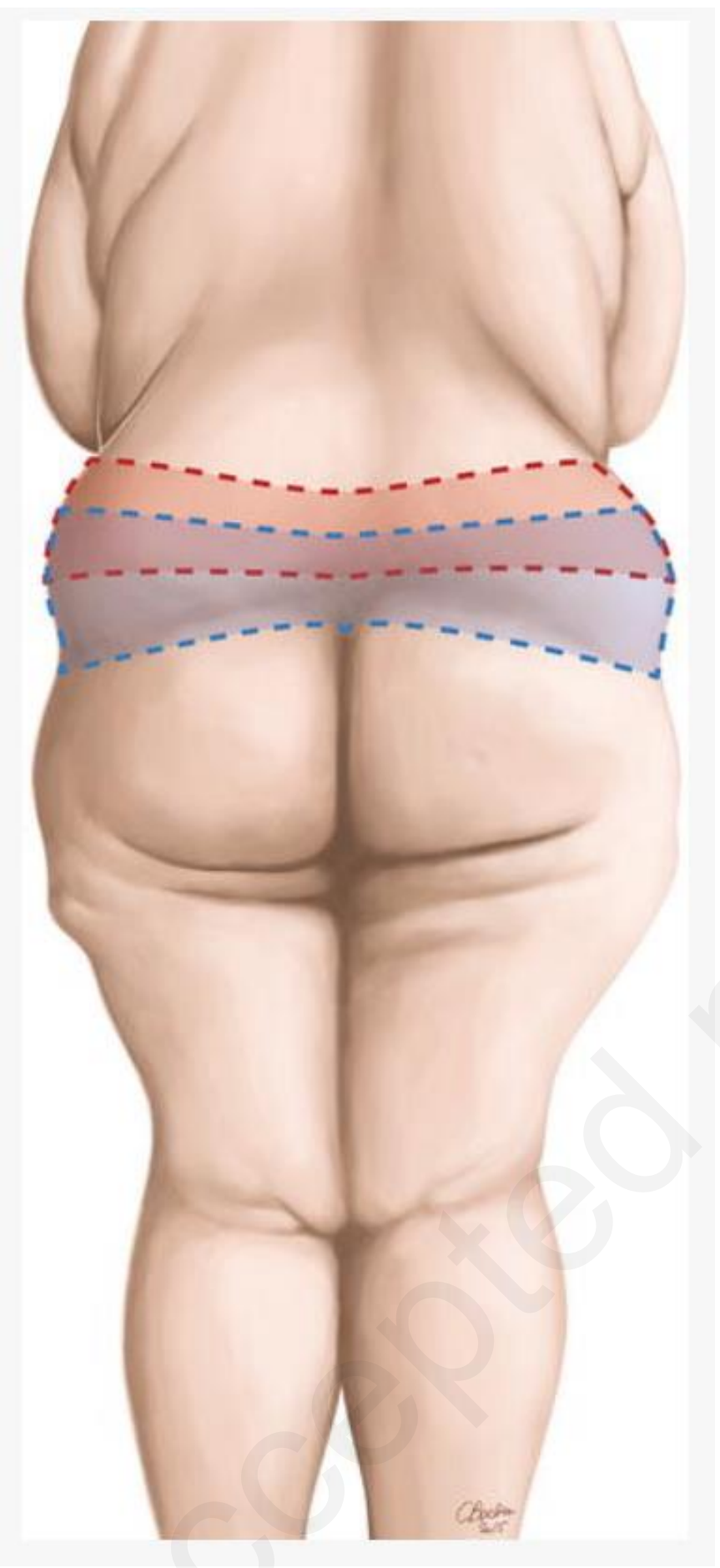

Figure 3. Skin patterns of belt lipectomy (red markings) and lower body lift (blue markings). For belt lipectomy: pattern is higher; superior resection line is drawn first at the superior margin of the flank rolls. For lower body lift: pattern is lower; inferior resection line is drawn first either inside or at the superior margin of the gluteal cleft. 


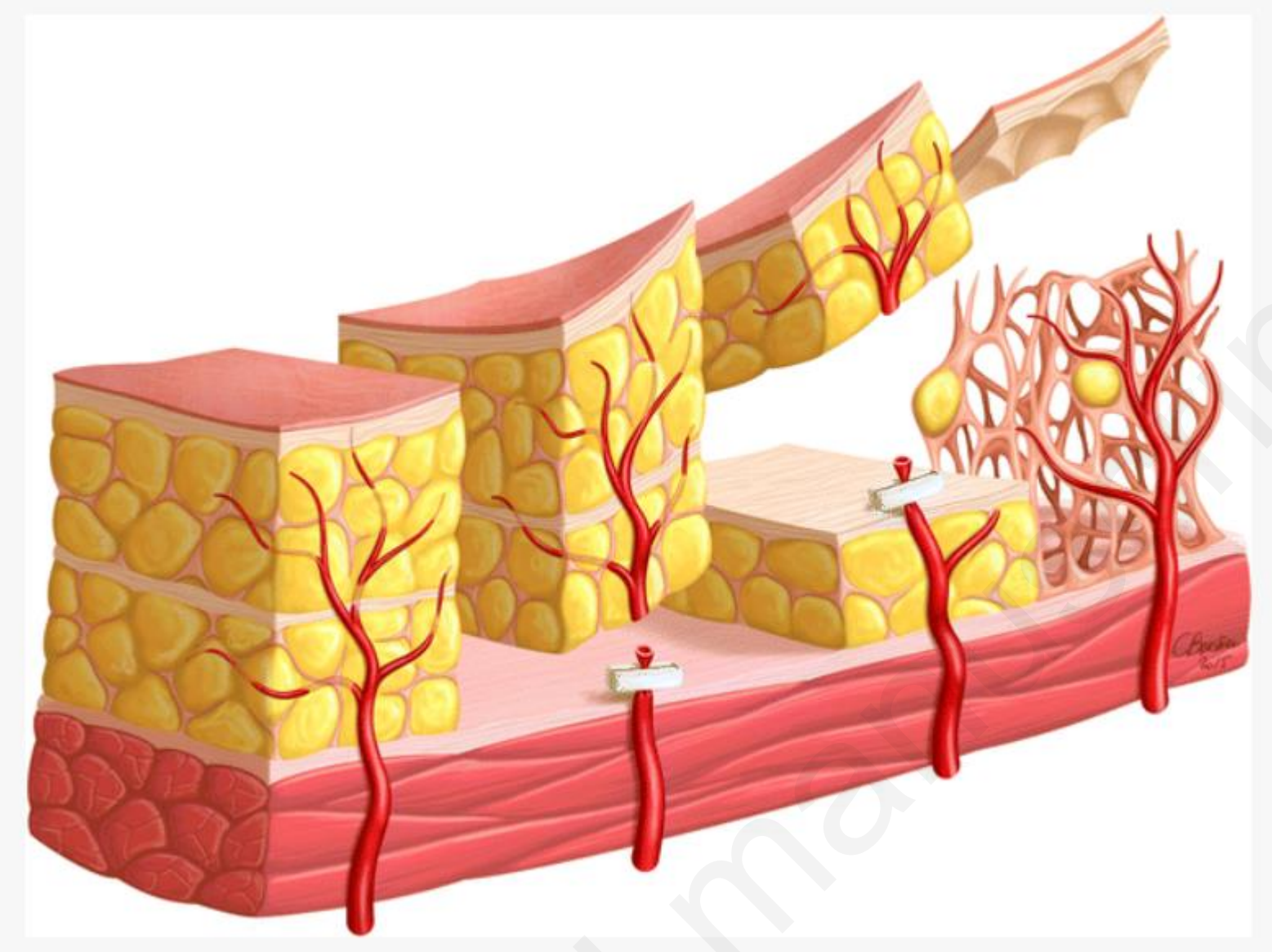

Figure 4. Different resection depths during posterior step: (1) to the muscular fascia, (2) to the superficial fascia or (3) under the dermis following liposuction of both superficial and deep fat. 


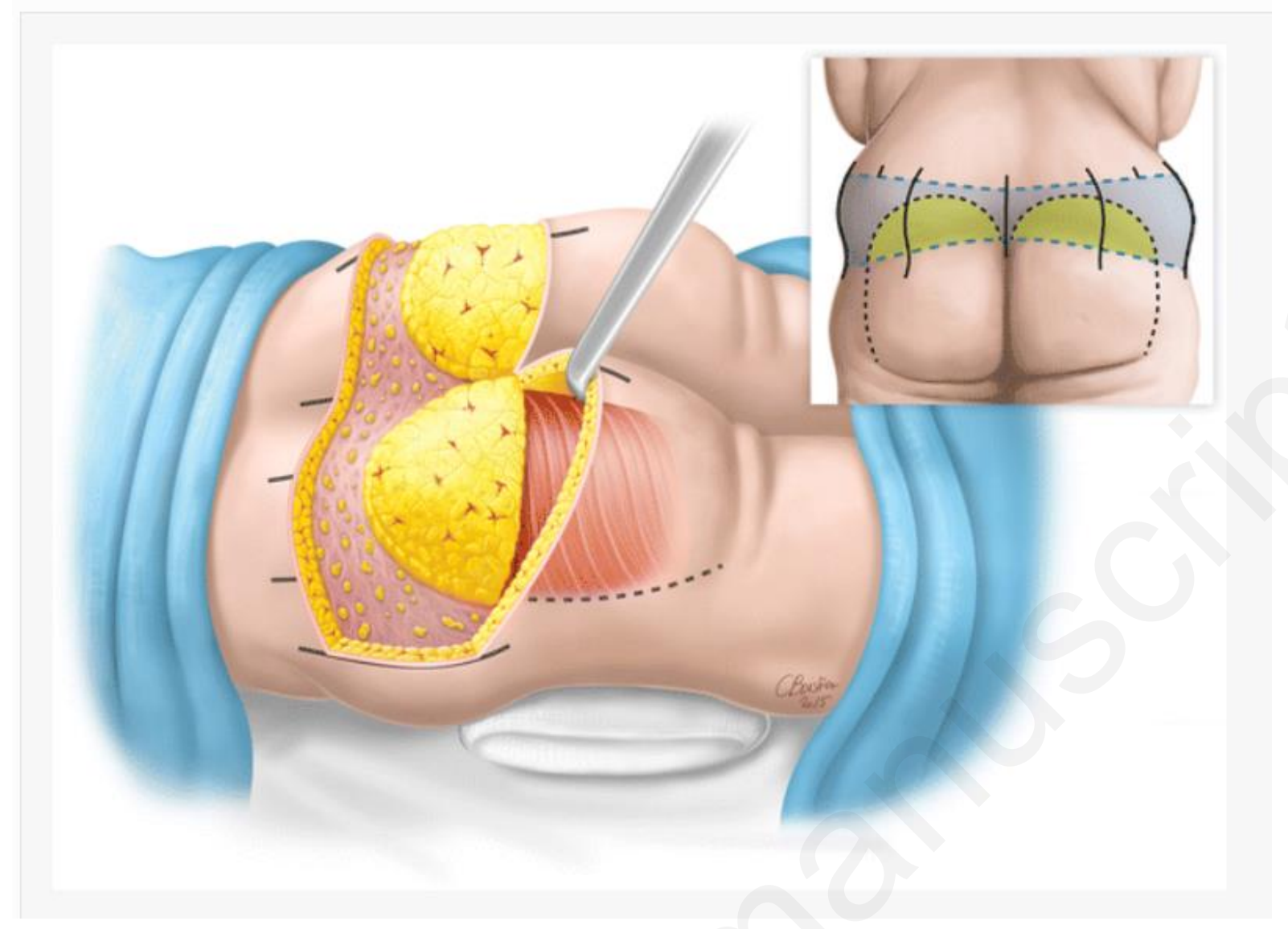

Figure 5. Technique of buttock augmentation with flap. An autologous dermal fat flap is dissected and moved down to the gluteal fold, after an undermine over the gluteus maximus muscle creating thus a "gluteal pocket". 


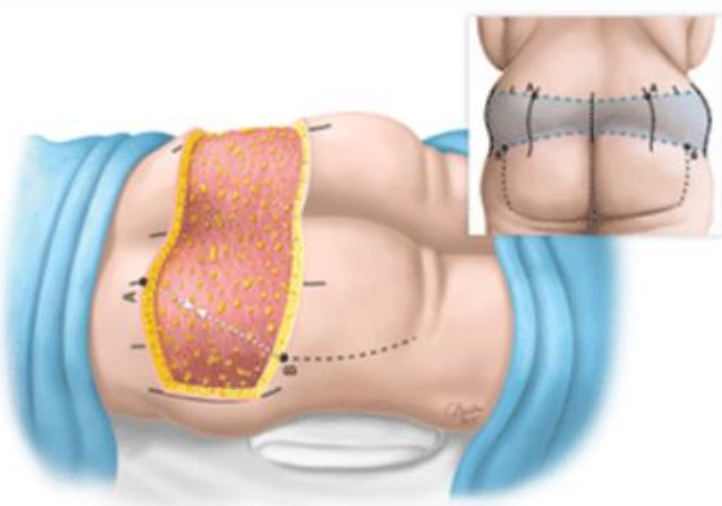

(a)

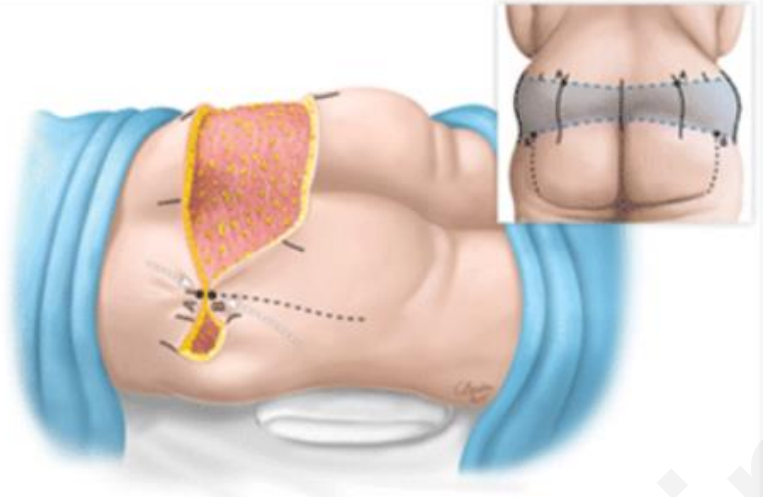

(b)

Figure 6. Technique of buttock augmentation without flap. a) Point B, located at the lateral end of the gluteal fold on the inferior resection line, is sutured to point $\mathrm{A}$, located $5 \mathrm{~cm}$ medially to point $\mathrm{B}$ on the superior resection line. $\mathrm{b}$ ) gluteal augmentation by suturing point B to point A. 
Table 1

Presentation of included articles, with level of evidence

\section{Article}

Gonzalez-Ulloa [4]
Vilain and Dubousset

[]ㅡ

Lockwood []

Lockwood [29]

Hunstad [46]

Carwell and Horton [9]

Van Geertruyden [10]

Hamra [26]

Lockwood [11]

Heddens [30]

Pascal and Le Louarn

[14]

Modolin et al. [22]

Morales Gracia [23]

Aly et al. [31]

Pascal and Le Louarn

[32]

Cormenzana and

Samprón [28]

Rohde and Gerut [33]

Van Huizum et al. [27] Netherlands

Sozer et al. [34]

Centeno [20]

Nemerofsky et al. [35] United States

\section{Country}

Spain

France

United States

United States

United States

United States

Belgium

United States

United States

United States

France

Brazil

Mexico

United States

France

Spain

United States

United States

United States

Retrospective

description

Retrospective cohort

\section{Case Series}

Technical description

Technical description

Case Series

Retrospective cohort

Retrospective cohort

Technical description

Retrospective cohort

Retrospective cohort

Retrospective cohort

Retrospective cohort

Retrospective cohort

Retrospective cohort

Retrospective cohort

Retrospective cohort

Retrospective cohort

Retrospective cohort
Evidence Number of included

level

patients
Retrospective

V

2

150

III

IV

10

III

32

III

40

III

III

III

100

III

20

III

62

III

III

20

III

III 


\begin{tabular}{|c|c|c|c|c|}
\hline Article & Country & Study design & $\begin{array}{l}\text { Evidence } \\
\text { level }\end{array}$ & $\begin{array}{c}\text { Number of included } \\
\text { patients }\end{array}$ \\
\hline Rohrich et al. [21] & United States & $\begin{array}{l}\text { cohort } \\
\text { Retrospective } \\
\text { cohort }\end{array}$ & III & 151 \\
\hline Strauch et al. [19] & United States & $\begin{array}{l}\text { Retrospective } \\
\text { cohort }\end{array}$ & III & 75 \\
\hline $\begin{array}{l}\text { Colwell and Borud } \\
{[36]}\end{array}$ & United States & $\begin{array}{l}\text { Retrospective } \\
\text { cohort }\end{array}$ & III & 18 \\
\hline Davison et al. [49] & United States & Case Series & IV & 3 \\
\hline Aly et al. [50] & United States & $\begin{array}{l}\text { Technical } \\
\text { description }\end{array}$ & $\mathrm{V}$ & 0 \\
\hline Hatef et al. [51] & United States & $\begin{array}{l}\text { Retrospective } \\
\text { cohort }\end{array}$ & III & 65 \\
\hline Shermak et al. [45] & United States & $\begin{array}{l}\text { Retrospective } \\
\text { cohort }\end{array}$ & III & 57 \\
\hline Jones and Toft [47] & $\begin{array}{l}\text { United } \\
\text { Kingdom }\end{array}$ & $\begin{array}{l}\text { Retrospective } \\
\text { cohort }\end{array}$ & III & 16 \\
\hline Dini et al. [48] & Italy & $\begin{array}{l}\text { Retrospective } \\
\text { cohort }\end{array}$ & III & 41 \\
\hline $\begin{array}{l}\text { Kolker and Lampert } \\
\text { [37] }\end{array}$ & United States & $\begin{array}{l}\text { Retrospective } \\
\text { cohort }\end{array}$ & III & 24 \\
\hline Vico et al. [표 & Belgium & $\begin{array}{l}\text { Retrospective } \\
\text { cohort }\end{array}$ & III & 80 \\
\hline $\begin{array}{l}\text { Koller and Hintringer } \\
{[15]}\end{array}$ & Austria & $\begin{array}{l}\text { Retrospective } \\
\text { cohort }\end{array}$ & III & 50 \\
\hline $\begin{array}{l}\text { Koller and Hintringer } \\
{[16]}\end{array}$ & Austria & $\begin{array}{l}\text { Letter to the } \\
\text { editor }\end{array}$ & $\mathrm{V}$ & 1 \\
\hline Koller et al. [52] & Austria & $\begin{array}{l}\text { Prospective } \\
\text { cohort }\end{array}$ & II & 27 \\
\hline Kitzinger et al. [39] & Austria & $\begin{array}{l}\text { Prospective } \\
\text { cohort }\end{array}$ & II & 50 \\
\hline Buchanan et al. [누] & United States & $\begin{array}{l}\text { Retrospective } \\
\text { cohort }\end{array}$ & III & 35 \\
\hline Baca et al. [41] & United States & $\begin{array}{l}\text { Retrospective } \\
\text { cohort }\end{array}$ & III & 59 \\
\hline Aly et al. [44] & United States & $\begin{array}{l}\text { Technical } \\
\text { description }\end{array}$ & $\mathrm{V}$ & 1 \\
\hline De Runz et al. $[\underline{42}, \underline{64}]$ & France & $\begin{array}{l}\text { Retrospective } \\
\text { cohort }\end{array}$ & III & 55 \\
\hline Koller [1] & Austria & $\begin{array}{l}\text { Letter to the } \\
\text { editor }\end{array}$ & $\mathrm{V}$ & 1 \\
\hline Srivastava et al. [43] & United States & $\begin{array}{l}\text { Retrospective } \\
\text { cohort }\end{array}$ & III & 97 \\
\hline
\end{tabular}


Table 2

Geographical distribution of publications and number of patients

\begin{tabular}{|l|l|l|}
\hline Country of origin & Number of articles & Number of patients \\
\hline United States & 24 & 1013 \\
\hline Austria & 5 & 345 \\
\hline France & 4 & 110 \\
\hline Belgium & 2 & 22 \\
\hline Spain & 2 & 41 \\
\hline Italy & 1 & 39 \\
\hline Mexico & 1 & 21 \\
\hline Netherlands & 1 & 16 \\
\hline United Kingdom & 1 & 12 \\
\hline Brazil & 1 & 1748 \\
\hline Total & 42 & 345 \\
\hline
\end{tabular}


Table 3

Patient characteristics

\begin{tabular}{|c|c|c|c|c|c|}
\hline & $\begin{array}{l}\text { Articles } \\
\text { including data } \\
\text { (n) }\end{array}$ & Median [IQR] & $\begin{array}{l}\text { Mean } \pm 95 \% \\
\text { CI }\end{array}$ & Min & $\operatorname{Max}$ \\
\hline Age (years) & 15 & $41[40-44]$ & $41.25 \pm 2.16$ & 18 & 70 \\
\hline Female (\%) & 19 & $88[84-95]$ & $88.4 \pm 3.6$ & 75 & 100 \\
\hline $\mathrm{BMI}\left(\mathrm{kg} / \mathrm{m}^{2}\right)$ & 14 & $\begin{array}{l}28.6 \\
{[27.8-29.5]}\end{array}$ & $29.2 \pm 1.6$ & 20.2 & 39.8 \\
\hline $\begin{array}{l}\text { Max BMI } \\
\left(\mathrm{kg} / \mathrm{m}^{2}\right)\end{array}$ & 6 & $\begin{array}{l}50.6 \\
{[50.11-52.05]}\end{array}$ & $5^{2.96} \pm 4.41$ & 36.2 & 104.1 \\
\hline $\begin{array}{l}\text { Loss of weight } \\
(\mathrm{kg})\end{array}$ & 9 & $49.6[44-60.5]$ & $53 \cdot 31 \pm 10.11$ & o & 200 \\
\hline $\begin{array}{l}\text { Loss of BMI } \\
\left(\mathrm{kg} / \mathrm{m}^{2}\right)\end{array}$ & 7 & $\begin{array}{l}22.2 \\
{[20.66-23.02]}\end{array}$ & $21.97 \pm 1.74$ & 12 & 28 \\
\hline $\begin{array}{l}\text { Time for weight } \\
\text { loss (years) }\end{array}$ & 1 & $2.95[2.07-3.77]$ & $2.96 \pm 1.08$ & 1.2 & 4.9 \\
\hline
\end{tabular}

$I Q R$ inter-quartile range, $C I$ confidence interval 
Indications and operative techniques

\begin{tabular}{|c|c|c|c|c|c|c|}
\hline Article & Indication & $\begin{array}{c}\text { Patient } \\
\text { positioning }\end{array}$ & $\begin{array}{l}\text { Operative } \\
\text { technique }\end{array}$ & $\begin{array}{c}\text { Buttock } \\
\text { augmentation }\end{array}$ & $\begin{array}{c}\text { Buttock } \\
\text { Resection } \\
\text { depth }\end{array}$ & Liposuction \\
\hline $\begin{array}{l}\text { Gonzalez- } \\
\text { Ulloa [4] }\end{array}$ & $\begin{array}{l}\text { Post } \\
\text { pregnancy, } \\
\text { obese, post- } \\
\text { diet weight } \\
\text { loss }\end{array}$ & $\begin{array}{l}\text { Supine then } \\
\text { prone }\end{array}$ & $\begin{array}{l}\text { Belt } \\
\text { lipectomy }\end{array}$ & No & $\begin{array}{l}\text { Muscular } \\
\text { fascia }\end{array}$ & No \\
\hline $\begin{array}{l}\text { Vilain and } \\
\text { Dubousset } \\
\text { [] }\end{array}$ & $\begin{array}{l}\text { Post-diet } \\
\text { weight loss }\end{array}$ & $\begin{array}{l}\text { Supine then } \\
\text { prone }\end{array}$ & $\begin{array}{l}\text { Belt } \\
\text { lipectomy }\end{array}$ & No & $\begin{array}{l}\text { Muscular } \\
\text { fascia }\end{array}$ & No \\
\hline $\begin{array}{l}\text { Lockwood } \\
\text { [] }]\end{array}$ & $\begin{array}{l}\text { Truncal } \\
\text { excess } \\
\text { (normal } \\
\text { weight) }\end{array}$ & $\begin{array}{l}\text { Supine then } \\
\text { twice lateral }\end{array}$ & $\begin{array}{l}\text { Lower } \\
\text { body lift }\end{array}$ & NO & $\begin{array}{l}\text { Superficial } \\
\text { Fascial }\end{array}$ & Yes \\
\hline $\begin{array}{l}\text { Lockwood } \\
{[\underline{29]}}\end{array}$ & $\begin{array}{l}\text { Truncal } \\
\text { excess } \\
\text { (normal } \\
\text { weight) }\end{array}$ & $\begin{array}{l}\text { Supine then } \\
\text { twice lateral }\end{array}$ & $\begin{array}{l}\text { Lower } \\
\text { body lift }\end{array}$ & No & $\begin{array}{l}\text { Superficial } \\
\text { Fascial }\end{array}$ & Yes \\
\hline Hunstad [46] & Obese & $\begin{array}{l}\text { Supine then } \\
\text { prone }\end{array}$ & $\begin{array}{l}\text { Belt } \\
\text { lipectomy }\end{array}$ & No & $\begin{array}{l}\text { Muscular } \\
\text { fascia }\end{array}$ & Yes \\
\hline $\begin{array}{l}\text { Carwell and } \\
\text { Horton [9] }\end{array}$ & $\begin{array}{l}\text { Massive } \\
\text { weight loss } \\
\text { (bariatric } \\
\text { surgery or } \\
\text { diet) }\end{array}$ & $\begin{array}{l}\text { Prone then } \\
\text { supine }\end{array}$ & $\begin{array}{l}\text { Belt } \\
\text { lipectomy }\end{array}$ & No & $\begin{array}{l}\text { Muscular } \\
\text { fascia }\end{array}$ & Yes \\
\hline $\begin{array}{l}\text { Van } \\
\text { Geertruyden } \\
{[\underline{10]}}\end{array}$ & $\begin{array}{l}\text { Massive } \\
\text { weight loss } \\
\text { (bariatric } \\
\text { surgery or } \\
\text { diet) }\end{array}$ & $\begin{array}{l}\text { Prone then } \\
\text { supine }\end{array}$ & $\begin{array}{l}\text { Belt } \\
\text { lipectomy }\end{array}$ & No & $\begin{array}{l}\text { Muscular } \\
\text { fascia }\end{array}$ & Yes \\
\hline Hamra [26] & $\begin{array}{l}\text { Post } \\
\text { pregnancy, } \\
\text { massive } \\
\text { weight loss }\end{array}$ & $\begin{array}{l}\text { Supine then } \\
\text { twice lateral }\end{array}$ & $\begin{array}{l}\text { Belt } \\
\text { lipectomy }\end{array}$ & No & $\begin{array}{l}\text { Muscular } \\
\text { fascia }\end{array}$ & Yes \\
\hline $\begin{array}{l}\text { Lockwood } \\
\text { [11] }\end{array}$ & $\begin{array}{l}\text { Massive } \\
\text { weight loss }\end{array}$ & $\begin{array}{l}\text { Supine then } \\
\text { twice lateral }\end{array}$ & $\begin{array}{l}\text { Lower } \\
\text { body lift }\end{array}$ & No & $\begin{array}{l}\text { Superficial } \\
\text { Fascial }\end{array}$ & Yes \\
\hline $\begin{array}{l}\text { Heddens } \\
{[30]}\end{array}$ & $\begin{array}{l}\text { Bariatric } \\
\text { surgery or } \\
\text { diet }\end{array}$ & $\begin{array}{l}\text { Prone then } \\
\text { supine OR } \\
\text { Supine then } \\
\text { twice lateral }\end{array}$ & $\begin{array}{l}\text { Belt } \\
\text { lipectomy }\end{array}$ & No & $\begin{array}{l}\text { Muscular } \\
\text { fascia }\end{array}$ & Yes \\
\hline $\begin{array}{l}\text { Pascal and } \\
\text { Le Louarn } \\
{[14]}\end{array}$ & $\begin{array}{l}\text { Massive } \\
\text { weight loss }\end{array}$ & $\begin{array}{l}\text { Prone then } \\
\text { supine }\end{array}$ & $\begin{array}{l}\text { Lower } \\
\text { body lift }\end{array}$ & $\begin{array}{l}\text { Autologous } \\
\text { flap }\end{array}$ & $\begin{array}{l}\text { Muscular } \\
\text { fascia }\end{array}$ & Yes \\
\hline
\end{tabular}




\begin{tabular}{|c|c|c|c|c|c|c|}
\hline Article & Indication & $\begin{array}{c}\text { Patient } \\
\text { positioning }\end{array}$ & $\begin{array}{l}\text { Operative } \\
\text { technique }\end{array}$ & $\begin{array}{c}\text { Buttock } \\
\text { augmentation }\end{array}$ & $\begin{array}{c}\text { Buttock } \\
\text { Resection } \\
\text { depth }\end{array}$ & Liposuction \\
\hline $\begin{array}{l}\text { Modolin et } \\
\text { al. [22] }\end{array}$ & $\begin{array}{l}\text { Massive } \\
\text { weight loss } \\
\text { (bariatric } \\
\text { surgery) }\end{array}$ & $\begin{array}{l}\text { Prone then } \\
\text { supine }\end{array}$ & $\begin{array}{l}\text { Belt } \\
\text { lipectomy }\end{array}$ & No & $\begin{array}{l}\text { Muscular } \\
\text { fascia }\end{array}$ & NR \\
\hline $\begin{array}{l}\text { Morales } \\
\text { Gracia [23] }\end{array}$ & $\begin{array}{l}\text { Overweight } \\
(0-35 \mathrm{~kg})\end{array}$ & $\begin{array}{l}\text { Twice } \\
\text { lateral then } \\
\text { supine }\end{array}$ & $\begin{array}{l}\text { Belt } \\
\text { lipectomy }\end{array}$ & No & $\begin{array}{l}\text { Muscular } \\
\text { fascia }\end{array}$ & Yes \\
\hline $\begin{array}{l}\text { Aly et al. } \\
\text { [31] }\end{array}$ & $\begin{array}{l}\text { Massive } \\
\text { weight loss, } \\
\text { normal } \\
\text { weight, } \\
\text { overweight } \\
\text { or obese }\end{array}$ & $\begin{array}{l}\text { Prone then } \\
\text { supine OR } \\
\text { Supine then } \\
\text { twice lateral }\end{array}$ & $\begin{array}{l}\text { Belt } \\
\text { lipectomy }\end{array}$ & No & $\begin{array}{l}\text { Muscular } \\
\text { fascia }\end{array}$ & Yes \\
\hline $\begin{array}{l}\text { Pascal and } \\
\text { Le Louarn } \\
{[32]}\end{array}$ & $\begin{array}{l}\text { Massive } \\
\text { weight loss }\end{array}$ & $\begin{array}{l}\text { Prone then } \\
\text { supine }\end{array}$ & $\begin{array}{l}\text { Lower } \\
\text { body lift }\end{array}$ & $\begin{array}{l}\text { Autologous } \\
\text { flap }\end{array}$ & $\begin{array}{l}\text { Muscular } \\
\text { fascia }\end{array}$ & yes \\
\hline $\begin{array}{l}\text { Cormenzana } \\
\text { and } \\
\text { Samprón } \\
{[\underline{28}]}\end{array}$ & $\begin{array}{l}\text { Post } \\
\text { pregnancy, } \\
\text { obese or } \\
\text { massive } \\
\text { weight loss }\end{array}$ & NR & $\begin{array}{l}\text { Belt } \\
\text { lipectomy }\end{array}$ & No & NR & Yes \\
\hline $\begin{array}{l}\text { Rohde and } \\
\text { Gerut [33] }\end{array}$ & $\begin{array}{l}\text { Massive } \\
\text { weight loss } \\
\text { (bariatric } \\
\text { surgery) }\end{array}$ & $\begin{array}{l}\text { Supine then } \\
\text { prone }\end{array}$ & $\begin{array}{l}\text { Lower } \\
\text { body lift }\end{array}$ & $\begin{array}{l}\text { Autologous } \\
\text { flap }\end{array}$ & $\begin{array}{l}\text { Muscular } \\
\text { fascia }\end{array}$ & NR \\
\hline $\begin{array}{l}\text { Van Huizum } \\
\text { et al. [2] }\end{array}$ & $\begin{array}{l}\text { Post } \\
\text { pregnancy or } \\
\text { massive } \\
\text { weight loss }\end{array}$ & $\begin{array}{l}\text { Supine then } \\
\text { prone }\end{array}$ & $\begin{array}{l}\text { Belt } \\
\text { lipectomy }\end{array}$ & No & $\begin{array}{l}\text { Muscular } \\
\text { fascia }\end{array}$ & NR \\
\hline $\begin{array}{l}\text { Sozer et al. } \\
\text { [34] }\end{array}$ & $\begin{array}{l}\text { Massive } \\
\text { weight loss } \\
\text { (bariatric } \\
\text { surgery or } \\
\text { diet) }\end{array}$ & $\begin{array}{l}\text { Twice } \\
\text { lateral then } \\
\text { supine }\end{array}$ & $\begin{array}{l}\text { Lower } \\
\text { body lift }\end{array}$ & $\begin{array}{l}\text { Autologous } \\
\text { flap }\end{array}$ & $\begin{array}{l}\text { Muscular } \\
\text { fascia }\end{array}$ & Yes \\
\hline Centeno [20] & $\begin{array}{l}\text { Massive } \\
\text { weight loss }\end{array}$ & $\begin{array}{l}\text { Prone then } \\
\text { supine }\end{array}$ & $\begin{array}{l}\text { Lower } \\
\text { body lift }\end{array}$ & $\begin{array}{l}\text { Autologous } \\
\text { flap }\end{array}$ & $\begin{array}{l}\text { Muscular } \\
\text { fascia }\end{array}$ & NR \\
\hline $\begin{array}{l}\text { Nemerofsky } \\
\text { et al. [ㅍ] }\end{array}$ & $\begin{array}{l}\text { Massive } \\
\text { weight loss } \\
\text { (bariatric } \\
\text { surgery or } \\
\text { diet) }\end{array}$ & $\begin{array}{l}\text { Supine then } \\
\text { twice lateral }\end{array}$ & $\begin{array}{l}\text { Lower } \\
\text { body lift }\end{array}$ & No & $\begin{array}{l}\text { Muscular } \\
\text { fascia }\end{array}$ & Yes \\
\hline $\begin{array}{l}\text { Rohrich et } \\
\text { al. [21] }\end{array}$ & $\begin{array}{l}\text { Massive } \\
\text { weight loss } \\
\text { or truncal }\end{array}$ & $\begin{array}{l}\text { Prone then } \\
\text { supine }\end{array}$ & $\begin{array}{l}\text { Belt } \\
\text { lipectomy }\end{array}$ & No & $\begin{array}{l}\text { Muscular } \\
\text { fascia }\end{array}$ & Yes \\
\hline
\end{tabular}




\section{Article Indication $\begin{gathered}\text { Patient } \\ \text { positioning }\end{gathered} \quad \begin{aligned} & \text { Operative } \\ & \text { technique }\end{aligned}$ augmentation $\begin{gathered}\text { Buttock } \\ \text { Resection Liposuction } \\ \text { depth }\end{gathered}$}

excess

(normal

weight)

Massive

Strauch et al. weight

[19]

(bariatric

Supine then Belt

surgery)

Massive

Colwell and weight loss

Borud [36] (bariatric surgery)

prone lipectomy

No

Superficial NR

Fascia

Massive

Davison et

weight loss

al. [49]

(bariatric

surgery or

Supine then Belt

Prone then Lower

supine

body lift

Autologous

Muscular

fascia

NR

diet)

twice lateral lipectomy

No

Muscular

fascia

NR

Superficial

Aly et al. NR

Supine then Belt

[50]

twice lateral lipectomy

No

or

muscular Yes

fascia

Lower

Hatef et al.

[51]

NR

body lift or

belt

NR

NR

Lipectomy

Shermak et Massive

al. [45] weight loss

Lower body lift

NR

NR

NR

Massive

Jones and

weight loss Twice

Toft [47] (bariatric surgery or

lateral then

Lower

No

Superficial Yes
Fascia diet) supine

body lift

Massive

Dini et al. weight loss

[48]

(bariatric surgery or

Prone then Lower

Autologous

Muscular

supine

body lift flap

fascia

Yes diet)

Massive

Kolker and weight loss

Lampert

[37]

(bariatric surgery or

Prone then Lower supine body lift

No

Muscular Yes diet)

Vico et al. Massive [38] weight loss (bariatric

$\begin{array}{ll}\text { Prone then } & \text { Lower } \\ \text { supine } & \text { body lift }\end{array}$ No

Muscular fascia

NR 


\begin{tabular}{|c|c|c|c|c|c|c|}
\hline Article & $\begin{array}{l}\text { Indication } \\
\text { surgery or } \\
\text { diet) }\end{array}$ & $\begin{array}{c}\text { Patient } \\
\text { positioning }\end{array}$ & $\begin{array}{l}\text { Operative } \\
\text { technique }\end{array}$ & $\begin{array}{c}\text { Buttock } \\
\text { augmentation }\end{array}$ & $\begin{array}{c}\text { Buttock } \\
\text { Resection } \\
\text { depth }\end{array}$ & Liposuction \\
\hline $\begin{array}{l}\text { Koller and } \\
\text { Hintringer } \\
{[15]}\end{array}$ & $\begin{array}{l}\text { Massive } \\
\text { weight loss } \\
\text { (bariatric } \\
\text { surgery or } \\
\text { diet) }\end{array}$ & $\begin{array}{l}\text { Prone then } \\
\text { supine }\end{array}$ & $\begin{array}{l}\text { Lower } \\
\text { bodylift }\end{array}$ & Without flap & $\begin{array}{l}\text { Superficial } \\
\text { Fascia }\end{array}$ & $\mathrm{NR}$ \\
\hline $\begin{array}{l}\text { Koller and } \\
\text { Hintringer } \\
{[16]}\end{array}$ & NR & $\begin{array}{l}\text { Prone then } \\
\text { supine }\end{array}$ & $\begin{array}{l}\text { Lower } \\
\text { body lift }\end{array}$ & Without flap & $\begin{array}{l}\text { Superficial } \\
\text { Fascia }\end{array}$ & $\mathrm{NR}$ \\
\hline $\begin{array}{l}\text { Koller et al. } \\
{[52]}\end{array}$ & $\begin{array}{l}\text { Massive } \\
\text { weight loss } \\
\text { (bariatric } \\
\text { surgery) }\end{array}$ & $\begin{array}{l}\text { Prone then } \\
\text { supine }\end{array}$ & $\begin{array}{l}\text { Lower } \\
\text { body lift }\end{array}$ & NR & $\begin{array}{l}\text { Superficial } \\
\text { Fascia }\end{array}$ & NR \\
\hline $\begin{array}{l}\text { Kitzinger et } \\
\text { al. [39] }\end{array}$ & $\begin{array}{l}\text { Massive } \\
\text { weight loss } \\
\text { (bariatric } \\
\text { surgery or } \\
\text { diet) }\end{array}$ & $\begin{array}{l}\text { Prone then } \\
\text { supine }\end{array}$ & $\begin{array}{l}\text { Lower } \\
\text { body lift }\end{array}$ & No & $\begin{array}{l}\text { Superficial } \\
\text { Fascia }\end{array}$ & NR \\
\hline $\begin{array}{l}\text { Buchanan et } \\
\text { al. [며] }\end{array}$ & $\begin{array}{l}\text { Massive } \\
\text { weight loss } \\
\text { (bariatric } \\
\text { surgery or } \\
\text { diet) }\end{array}$ & $\begin{array}{l}\text { Supine then } \\
\text { prone }\end{array}$ & $\begin{array}{l}\text { Lower } \\
\text { body lift }\end{array}$ & No & $\begin{array}{l}\text { Muscular } \\
\text { fascia }\end{array}$ & Yes \\
\hline $\begin{array}{l}\text { Baca et al. } \\
\text { [41] }\end{array}$ & $\begin{array}{l}\text { Non post- } \\
\text { bariatric } \\
\text { surgery }\end{array}$ & NR & $\begin{array}{l}\text { Lower } \\
\text { body lift }\end{array}$ & NR & NR & Yes \\
\hline $\begin{array}{l}\text { Aly et al. } \\
{[44]}\end{array}$ & $\begin{array}{l}\text { massive } \\
\text { weight loss; } \\
\text { normal } \\
\text { weight or } \\
\text { overweight }\end{array}$ & $\begin{array}{l}\text { Supine then } \\
\text { twice lateral }\end{array}$ & $\begin{array}{l}\text { Belt } \\
\text { lipectomy }\end{array}$ & No & $\begin{array}{l}\text { Superficial } \\
\text { or } \\
\text { muscular } \\
\text { fascia }\end{array}$ & Yes \\
\hline $\begin{array}{l}\text { De Runz et } \\
\text { al. }[\underline{42}, \underline{64]}\end{array}$ & $\begin{array}{l}\text { Massive } \\
\text { weight loss } \\
\text { (bariatric } \\
\text { surgery or } \\
\text { diet) }\end{array}$ & $\begin{array}{l}\text { Prone then } \\
\text { supine }\end{array}$ & $\begin{array}{l}\text { Lower } \\
\text { body lift }\end{array}$ & $\begin{array}{l}\text { Autologous } \\
\text { flap }\end{array}$ & $\begin{array}{l}\text { Muscular } \\
\text { fascia }\end{array}$ & Yes \\
\hline Koller [ $\underline{18}]$ & $\begin{array}{l}\text { Massive } \\
\text { weight loss }\end{array}$ & $\begin{array}{l}\text { Prone then } \\
\text { supine }\end{array}$ & $\begin{array}{l}\text { Lower } \\
\text { body lift }\end{array}$ & No & $\begin{array}{l}\text { Skin-only } \\
\text { resection }\end{array}$ & Yes \\
\hline $\begin{array}{l}\text { Srivastava et } \\
\text { al. [43] }\end{array}$ & $\begin{array}{l}\text { Massive } \\
\text { weight loss } \\
\text { (bariatric } \\
\text { surgery or } \\
\text { diet) }\end{array}$ & $\begin{array}{l}\text { Prone then } \\
\text { supine }\end{array}$ & $\begin{array}{l}\text { Lower } \\
\text { body lift }\end{array}$ & $\begin{array}{l} \pm \text { Autologous } \\
\text { flap }\end{array}$ & $\begin{array}{l}\text { Muscular } \\
\text { fascia }\end{array}$ & NR \\
\hline
\end{tabular}


$N R$ not reported

Operative technique: techniques were classified as «Lower body lift» when the scar was situated at the bikini-line, as «Belt lipectomy» when the scar was situated at the waistline 
Table 5

Outcomes and complications

$\begin{array}{cccc}\text { Articles } & \text { Median } & \text { Mean } \pm 95 \% & \text { Min Max } \\ \text { including data } & {[\text { IQR }]} & \text { CI } & \end{array}$

Outcomes

\begin{tabular}{|c|c|c|c|c|c|}
\hline Resection weight (kg) & 10 & $\begin{array}{l}3.76[3.45- \\
4.45]\end{array}$ & $3.89 \pm 0.7$ & 0.69 & 15 \\
\hline Lipoaspirate volume (L) & 7 & $\begin{array}{l}1.68[1.27- \\
2.04]\end{array}$ & $1.87 \pm 0.79$ & 0.45 & 8.45 \\
\hline Operative time (min) & 14 & $\begin{array}{l}261[222.5- \\
306]\end{array}$ & $261.73 \pm 31.72$ & 79 & 654 \\
\hline Blood loss (L) & 5 & $\begin{array}{l}0.49[0.46- \\
0.63]\end{array}$ & $0.56 \pm 0.24$ & 0.2 & 1.9 \\
\hline Patients transfused (\%) & 15 & $13.75[0-22]$ & $21 \pm 14$ & 12.5 & 100 \\
\hline Length of stay (days) & 11 & $3.5[2.1-7.4]$ & $4.73 \pm 1.97$ & 0 & 32 \\
\hline \multicolumn{6}{|l|}{ Complications } \\
\hline Overall complications (\%) & 17 & $\begin{array}{l}36.55[26.63- \\
45.65]\end{array}$ & $35.01 \pm 7.66$ & & 70 \\
\hline Overall Revision rate (\%) & 22 & $\begin{array}{l}6.25[3.2- \\
13.9]\end{array}$ & $10.42 \pm 4.33$ & & 33 \\
\hline $\begin{array}{l}\text { Revision rate for aesthetic } \\
\text { purpose }(\%)\end{array}$ & 21 & $0[0-5.75]$ & $4.34 \pm 3.22$ & & 30 \\
\hline $\begin{array}{l}\text { Revision rate for non-aesthetic } \\
\text { purpose }(\%)\end{array}$ & 21 & $3.5[0.25-6]$ & $5.82 \pm 3.47$ & & 17 \\
\hline Wound dehiscence (\%) & 27 & $\begin{array}{l}13.51[9.38- \\
22.5]\end{array}$ & $19.54 \pm 6.81$ & & 68 \\
\hline Skin necrosis $(\%)$ & 27 & $0[0-2]$ & $1.51 \pm 0.88$ & & 10 \\
\hline Infection/abcess (\%) & 27 & $1.82[0-8]$ & $7.41 \pm 5.59$ & & 60 \\
\hline Hematoma (\%) & 27 & $0[0-2]$ & $1.42 \pm 0.88$ & & 10 \\
\hline Seroma $(\%)$ & 28 & $\begin{array}{l}9.45[4.76- \\
24.01]\end{array}$ & $14.46 \pm 4.78$ & & 46 \\
\hline Scar irregularities $(\%)$ & 12 & $\begin{array}{l}11.42[3.01- \\
17.59]\end{array}$ & $12.59 \pm 6.95$ & & 41 \\
\hline Thromboembolism (\%) & 28 & $0[0-1.70]$ & $1.53 \pm 1.20$ & & 13 \\
\hline
\end{tabular}

$I Q R$ inter-quartile range, $C I$ confidence interval 
Table 6

Antibiotic prophylaxis

\section{$\begin{array}{ccccccc}\text { Article } & \begin{array}{c}\text { Antibiotic } \\ \text { prophylaxis }\end{array} & \begin{array}{c}\text { Pre- } \\ \text { operative }\end{array} & \begin{array}{c}\text { Intra- } \\ \text { operative }\end{array} & \begin{array}{c}\text { Post- } \\ \text { operative }\end{array} & \text { Molecule } & \text { Posology }\end{array}$}

\begin{tabular}{|c|c|c|c|c|c|c|}
\hline $\begin{array}{l}\text { Gonzalez- } \\
\text { Ulloa [4] }\end{array}$ & NR & NR & NR & NR & NR & NR \\
\hline $\begin{array}{l}\text { Vilain and } \\
\text { Dubousset [5] }\end{array}$ & Yes & No & No & Yes & Penicillin & NR \\
\hline Lockwood [ㅁ] & Yes & NR & NR & NR & $\begin{array}{l}\text { Cephalexin } \\
(\mathrm{C} 1 \mathrm{G})\end{array}$ & NR \\
\hline $\begin{array}{l}\text { Lockwood } \\
\text { [29] }\end{array}$ & Yes & NR & NR & Yes & $\begin{array}{l}\text { Cephalexin } \\
\text { (C1G) }\end{array}$ & NR \\
\hline Hunstad [두] & Yes & NR & NR & Yes & NR & NR \\
\hline $\begin{array}{l}\text { Carwell and } \\
\text { Horton [9] }\end{array}$ & NR & NR & NR & NR & NR & NR \\
\hline $\begin{array}{l}\text { Van } \\
\text { Geertruyden } \\
{[10]}\end{array}$ & Yes & No & Yes & No & NR & NR \\
\hline Hamra [므] & Yes & NR & NR & Yes & NR & NR \\
\hline $\begin{array}{l}\text { Lockwood } \\
{[11]}\end{array}$ & Yes & Yes & Yes & Yes & NR & NR \\
\hline Heddens [ $[\underline{30}]$ & NR & NR & NR & NR & NR & NR \\
\hline $\begin{array}{l}\text { Pascal and Le } \\
\text { Louarn [14] }\end{array}$ & Yes & No & Yes & Yes & NR & NR \\
\hline $\begin{array}{l}\text { Modolin et al. } \\
{[\underline{22}]}\end{array}$ & Yes & No & Yes & No & $\begin{array}{l}\text { Cephalothin } \\
\text { (C1G) }\end{array}$ & $\begin{array}{l}2 \text { g intra- } \\
\text { operatively }\end{array}$ \\
\hline $\begin{array}{l}\text { Morales } \\
\text { Gracia [23] }\end{array}$ & Yes & No & Yes & No & $\begin{array}{l}\text { Cephalothin } \\
\text { (C1G) }\end{array}$ & $\begin{array}{l}1 \text { g intra- } \\
\text { operatively }\end{array}$ \\
\hline Aly et al. [31] & NR & NR & NR & NR & NR & NR \\
\hline $\begin{array}{l}\text { Pascal and Le } \\
\text { Louarn [32] }\end{array}$ & Yes & No & Yes & Yes & NR & NR \\
\hline $\begin{array}{l}\text { Cormenzana } \\
\text { and Samprón } \\
{[\underline{28]}}\end{array}$ & NR & NR & NR & NR & NR & NR \\
\hline $\begin{array}{l}\text { Rohde and } \\
\text { Gerut [33] }\end{array}$ & NR & NR & NR & NR & NR & NR \\
\hline $\begin{array}{l}\text { Van Huizum } \\
\text { et al. [27] }\end{array}$ & NR & NR & NR & NR & NR & NR \\
\hline $\begin{array}{l}\text { Sozer et al. } \\
\text { [34] }\end{array}$ & NR & NR & NR & NR & NR & NR \\
\hline Centeno [20] & Yes & No & Yes & Yes & NR & NR \\
\hline $\begin{array}{l}\text { Nemerofsky } \\
\text { et al. }[35]\end{array}$ & Yes & NR & NR & Yes & NR & NR \\
\hline
\end{tabular}




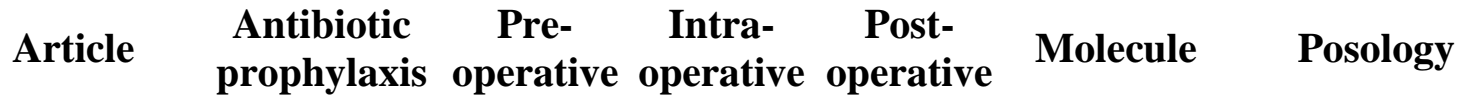

Rohrich et al. Yes

[21]

Strauch et al. Yes [19]

Colwell and

Borud [36] Yes

Davison et al. NR [49]

Aly et al. [50] NR

Hatef et al.

[51]

Shermak et al. NR [45]

Jones and

Toft [47]

Dini et al.

[48]

Kolker and

Lampert [37] NR

Vico et al. [38]

Yes

Koller and

Hintringer NR

[15]

Koller and

Hintringer NR

[16]

Koller et al. [52]

NR

Kitzinger et

al. [39]

Yes

Buchanan et NR

al. [40]

Baca et al.

[41]

Aly et al. [44] NR

De Runz et al. Yes

$[\underline{42}, \underline{64]}$
Yes NR

No Yes

No Yes

NR NR

NR NR

NR NR

NR

NR

No Yes

No

Yes

NR

NR

NR

NR

NR

NR

NR

Yes

NR

NR

Cefazolin $1 \mathrm{~g}$ intra-

(C1G) operatively

NR

NR

NR

NR

NR

NR

NR

Cefuroxime $1,5 \mathrm{~g}$ intra-

(C2G) operatively

NR

NR

NR

NR

$1 \mathrm{~g}$ intra-

Cefazolin operatively, (C1G) $1 \mathrm{~g} \times 3 /$ day during $24 \mathrm{~h}$ after surgery

NR NR

NR

NR

NR

NR NR NR

NR

NR

NR

NR

NR

NR

NR

2 g intra-

Cefuroxime operatively,

(C2G) $\quad 2 \mathrm{~g} \times 2 /$ day

during 3 days

after surgery

NR NR NR

NR

NR

NR NR

NR

NR

NR

NR NR

NR

NR

NR

No Yes

No

Cefazolin

(C1G)

NR 


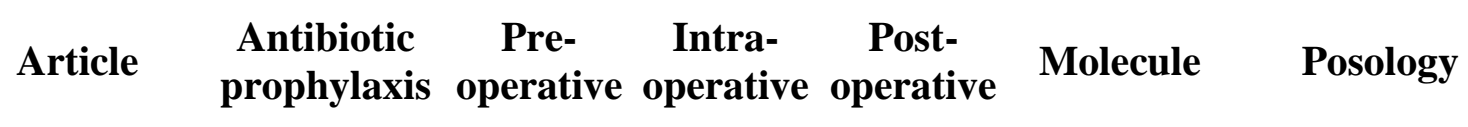

$\begin{array}{lllllll}\begin{array}{l}\text { Koller [18] } \\ \text { Srivastava et }\end{array} & \text { NR } & \text { NR } & \text { NR } & \text { NR } & \text { NR } & \text { NR } \\ \begin{array}{l}\text { al. [43] } \\ \text { NR }\end{array} & \text { NR } & \text { NR } & \text { NR } & \text { NR } & \text { NR }\end{array}$

$N R$ not reported, $C 1 G$ first-generation cephalosporin, $C 2 G$ second-generation cephalosporin 
Table 7

Thrombo-prophylaxis

Article $\begin{gathered}\text { Early } \\ \text { deambulation }\end{gathered} \begin{gathered}\text { Compression Pneumatic } \\ \text { stockings }\end{gathered} \underset{\text { stockings }}{\text { Chemioprophylaxis }}$ Molecule

$\begin{array}{llll}\text { Gonzalez- } & \text { NR } & \text { NR } & \text { NR }\end{array}$

Ulloa [4]

Vilain and

Dubousset Yes

[5]

Lockwood NR

[] ]

NR NR

NR

NR

NR

Lockwood NR

[29]

NR

NR

NR

Hunstad NR

NR

NR

NR

Carwell and

No

Yes

No

Van

Geertruyden Yes

[10]

Hamra [26] NR

Yes

No

Yes

LMWH

Lockwood

NR

Yes

No

No

[11]

NR

NR

NR

Heddens

[30]

Yes

No

No

Pascal and

Le Louarn Yes

Yes

No

Yes

LMWH

[14]

Modolin et

al. [22]

NR

Yes

No

Yes

LMWH

Morales

Gracia [23] Yes

NR

NR

Yes

UH

Aly et al.

Yes

No

Yes

$\pm$

(5000UI/day)

Pascal and

Le Louarn Yes

[32]

Cormenzana

and

Samprón

NR

NR

NR

NR

[28]

Rohde and NR

NR

NR

NR

Van Huizum NR

NR

NR

NR 
Article $\begin{gathered}\text { Early } \\ \text { deambulation }\end{gathered} \begin{gathered}\text { Compression Pneumatic } \\ \text { stockings }\end{gathered} \underset{\text { stockings }}{\text { Chemioprophylaxis }}$ Molecule

et al. [27]

Sozer et al.

[34]

NR

NR

NR

Centeno

NR

(1)

[20]

Yes

No

Yes

$\pm$

LMWH or

Nemerofsky Yes

et al. [35]

No

Yes

Fondaparinux

Rohrich et

al. [21]

Yes

No

Yes

LMWH

(Enoxaparin

3000UIx 2/day)

until hospital

discharge

Strauch et

Yes

No

LMWH until

al. [19]

Yes $\quad$ Yes

hospital

discharge

Colwell and Yes

No

Yes

No

Davison et

al. [49]

NR

NR

NR

NR

Aly et al.

[50]

NR

NR

NR

NR

Hatef et al.

[51]

NR

NR

NR

$\pm$

LMWH

Shermak et NR

al. [45]

NR

NR

NR

Jones and

Yes

No

Yes

No

Toft [47]

Dini et al.

[48]

NR

NR

Yes

LMWH for

1 week after hospital

discharge

Kolker and

Lampert Yes

[37]

Yes

No

No

Vico et al.

[38]

NR

NR

Yes

LMWH

(Enoxaparin

4000UI/day)

Koller and

Hintringer NR

NR

NR

NR

[15]

Koller and

Hintringer NR

[16]

Koller et al. NR

NR

NR

NR

NR

NR

NR 


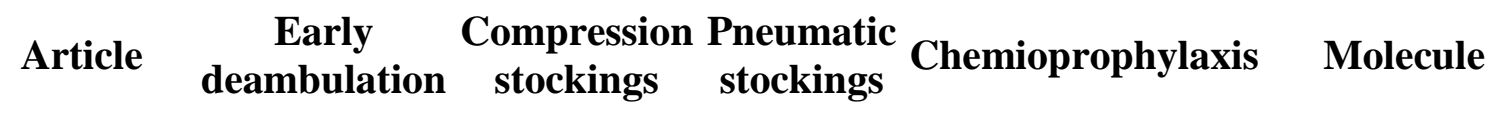
[52]

\begin{tabular}{|c|c|c|c|c|c|}
\hline $\begin{array}{l}\text { Kitzinger et } \\
\text { al. [39] }\end{array}$ & NR & Yes & No & Yes & $\begin{array}{l}\text { LMWH for } \\
6 \text { weeks after } \\
\text { hospital } \\
\text { discharge }\end{array}$ \\
\hline $\begin{array}{l}\text { Buchanan et } \\
\text { al. [40] }\end{array}$ & NR & No & Yes & Yes & $\begin{array}{l}\text { UH } \\
(5000 \mathrm{UI} / \text { day) } \\
\text { or LMWH } \\
\text { (Enoxaparin } \\
4000 \mathrm{UI} / \text { day) } \\
\text { for } 2 \text { days }\end{array}$ \\
\hline $\begin{array}{l}\text { Baca et al. } \\
\text { [41] }\end{array}$ & NR & NR & NR & NR & \\
\hline $\begin{array}{l}\text { Aly et al. } \\
{[44]}\end{array}$ & Yes & NR & NR & NR & \\
\hline $\begin{array}{l}\text { De Runz et } \\
\text { al. }[\underline{42}, \underline{64]}]\end{array}$ & Yes & Yes & No & Yes & $\begin{array}{l}\text { LMWH } \\
\text { (Enoxaparin } \\
4000 \mathrm{UI} / \text { day) } \\
\text { for } 2 \text { weeks } \\
\text { after hospital } \\
\text { discharge }\end{array}$ \\
\hline Koller [1] & NR & NR & NR & NR & \\
\hline $\begin{array}{l}\text { Srivastava et } \\
\text { al. [ㅍ] }\end{array}$ & NR & NR & NR & NR & \\
\hline
\end{tabular}

$N R$ not reported, $L M W H$ low molecular weight heparin, $U H$ unfractionated heparin 